\title{
Chemometrics, Health Risk Assessment and Probable Sources of Total Petroleum Hydrocarbons in Atmospheric Rainwater in Rivers State, Nigeria.
}

\section{Daniel Omokpariola}

Nnamdi Azikiwe University

John Nduka ( $\sim$ johnnduka2000@yahoo.co.uk)

Nnamdi Azikiwe University

Henrietta Kelle

National Open University of Nigeria

MaryAnn Mgbemena

Michael Okpara University of Agriculture

Emily Iduseri

National Open University of Nigeria

\section{Research Article}

Keywords: Atmospheric rainwater, TPHs, Chemometrics and risk assessment, Carbon preference index, Average carbon length, Nigeria

Posted Date: October 27th, 2021

DOl: https://doi.org/10.21203/rs.3.rs-967523/v1

License: (c) (1) This work is licensed under a Creative Commons Attribution 4.0 International License. Read Full License 
Chemometrics, health risk assessment and probable sources of total petroleum hydrocarbons in atmospheric rainwater in Rivers State, Nigeria.

\title{
By
}

\section{Daniel Omeodisemi ${ }^{1}$ Omokpariola, John Kanayochukwu ${ }^{* 1}$ Nduka, Henrietta Ijeoma ${ }^{2}$ Kelle, MaryAnn Nkoli ${ }^{3}$ Mgbemena, Emily Osa ${ }^{2}$ Iduseri}

${ }^{\mathbf{1} E n v i r o n m e n t a l}$ Chemistry and Toxicology Unit, Pure and Industrial Chemistry Department, Nnamdi Azikiwe University, P.M.B. 5025, Awka, Nigeria.

${ }^{2}$ Department of Environmental Sciences, Faculty of Science, National Open University Abuja. Nigeria

${ }^{2}$ Department of Chemistry, Faculty of Science, National Open University Abuja. Nigeria

${ }^{3}$ Department of Chemistry. Michael Okpara University of Agriculture, Umudike, Abia State Nigeria Email address: johnnduka2000@yahoo.co.uk; +234 (0) 7039541583

\begin{abstract}
Total petroleum hydrocarbons (TPHs)-(aliphatic and aromatic) were analysed for in atmospheric rainwater between April- June; July - August; September-October depicting early, mid, late rain of 2019. Sampling at Rumuodomaya/ Rumuodome and Ogale in Rivers State using basins fastened to a table $2 \mathrm{M}$ above ground and $120 \mathrm{M}$ from high features, Rainwater was analysed after treatment using Agilent GC-FID. Results show cumulative TPHs at R/R were $56.6551 \mathrm{mg} / \mathrm{L}, 39.5201 \mathrm{mg} / \mathrm{L}$ and 7.2283mg/L, Ogale: $9.1217 \mathrm{mg} / \mathrm{L}, 59.4923 \mathrm{mg} / \mathrm{L}$ and $21.9825 \mathrm{mg} / \mathrm{L}$. Aliphatic hydrocarbons: C5 - C8 were $<1$, low contamination, other carbon aggregates $(\mathrm{C} 9-\mathrm{C} 16, \mathrm{C} 17-\mathrm{C} 35$, and $\mathrm{C} 36-\mathrm{C} 40)$ indicate high contamination. Chemometric assessment showed high contamination. TPHs aggregates at Rumuodomaya/ Rumuodome were- C8 - C11 (1.034 and 1.005) early rain, C18 - C25 and C26 C33 has Carbon preference index of 1.287 and 1.630 (mid-rain), C26 - C33 has CPI of 1.288 (laterain), Ogale area, C26-C33 has CPI of 1.732 (early-rain), mid-rain C8 - C11 (2.768) and C12-C17 (5.368). Pristane/phytane ratio indicated biogenic and pyrogenic sources. Average carbon length of TPHs for odd n-alkanes were C9 - C11 (9.446) and C35 - C39 (38.980), C9 - C11(10.238), C35 C39 (36.510); C9 - C11 (10.240) and C35 - C39 (36.934). Average daily intake depicted possible health issues for children and adults as hazard index $>1$ for aromatics.
\end{abstract}

Keywords: Atmospheric rainwater; TPHs; Chemometrics and risk assessment; Carbon preference index; Average carbon length; Nigeria 


\section{Introduction}

Rivers State Nigeria has been a petroleum exploration and exploitation hotspot for over 50 years covering a land mass of about 10,575 square kilometres [1]. There is continuous wet and dry season through the year resulting from the impact of the Atlantic Ocean and Sahara Desert continental air masses. Annual rainfall ranges from $1900-2850 \mathrm{~mm}$, temperature varies from $22.6-34.0^{\circ} \mathrm{C}$, relative humidity between $65-80 \%$ [1]. Different local and international oil companies situated onshore and offshore with downstream petroleum depots and filling stations surround major oil-producing communities and connect several pipelines and flow stations. These activities may likely result in the release of environmental contaminants such as polynuclear aromatic hydrocarbons (PHAs), aliphatic hydrocarbons, heavy metals, organometallic compounds, aerosols, ashes, particulates, $\mathrm{H}_{2} \mathrm{~S}, \mathrm{CO}_{\mathrm{X}}$, $\mathrm{NO}_{\mathrm{X}}, \mathrm{SO}_{\mathrm{X}}$, soot, smoke, etc into the atmosphere as activities of petroleum companies are intense in Nigeria's crude oil and gas-bearing region reputed to house several billions of crude oil and trillions of cubic feet of natural gas [2]. Out of several environmental contaminants that may be released, total petroleum hydrocarbons (TPHs) stand out and are chemical compounds produced by phytogenic (plants, animal and microbes), petrogenic (crude oil, gas, and coal), and pyrogenic (natural and anthropogenic) combustion of carbonaceous component [3].

They are made from carbon and hydrogen compounds that range from $\mathrm{C}_{5}-\mathrm{C}_{40}$ with aromatic (cyclic ring) such as polycyclic aromatic hydrocarbons, BTEX (benzene, toluene, ethylbenzene, and xylene), asphaltenes, prophrins, NSO (nitrogen, sulphur, oxygen) compounds, etc. and aliphatic saturates (straight-chain, branched-chain and cyclic alkanes) such as paraffins, isoprenoids, naphthenes, etc [4]. Suitable environmental conditions can activate the formation of toxic polychlorinated-n-alkanes of formula $\mathrm{CnH}_{2} \mathrm{n}+2-2 \mathrm{X}_{2}$ (X is chlorine of halogen group) [5], C10 - C13 carbon chain has the most probable environmental emission [6], as a result of photolysis, hydrolysis, oxidation, and biodegradation (degradation processes) transform chemical compounds upon entry into its environmental recipient, They are released across environmental matrices (lithosphere, hydrosphere, and atmosphere) by human activities such as petroleum exploration and drilling process, industrial effluents, accidental spills, automobile releases, petroleum transport and depot storage, which causes tremendous contamination over the cumulative period $[7,8,9]$. Pyrogenic, petrogenic, and phytogenic emission into the atmosphere leads to high deposition of particulates on different surfaces.

Rainfall washes these particulates and gases out from the atmosphere. Several assessments have shown that TPH influences inorganic parameters of water such as $\mathrm{pH}$, temperature, dissolved oxygen, total solids, and turbidity already reported [7, 10]. A higher amount of these petroleum chemicals reacts physiochemically and biologically across environmental matrices leading to the production of persistent organic pollutants (POPs), micro particulates, and sediments triggering a high risk of bioaccumulation in humans that may result in mental, genetic, immune, endocrine-disruption, respiratory, teratogenic and carcinogenic effects $[11,12]$. Previous studies have focused on TPHs in soil and sediment, aquatic species, and marine sources $[13,14,15]$, while polyaromatic hydrocarbon (PAHs) in soils and surface water of the region has received voluminous literature [16, 17] and consistently proved the negative impact to flora and faunas of the study area by organic emissions from various activities previously enumerated above, however, we are not aware of any literature evidence of TPH via atmospheric rainwater deposition in Nigeria, this forms the basis of our research. The reason for this work is to i) to estimate the TPHs in atmospheric rainwater in crude oil and gas region of Nigeria ii) source identification iii) evaluation of carbon preference index and average carbon length and iv) non-carcinogenic risk assessment of TPH. 


\section{Materials and Methods}

\subsection{Sample collection and preparation}

Rainwater samples were collected from ambient (open-air) in Ogale (O/E), Eleme local government

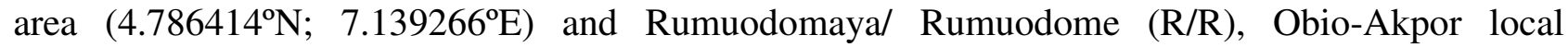
government area $\left(4.856923^{\circ} \mathrm{N} ; 7.014726^{\circ} \mathrm{E}\right)$ in Rivers State, Nigeria between the months of April May (early rain), June - August (mid rain) and September - November (late rain) in 2019 using precleaned amber glass bottles. Sampling was at different locations of Rumuodomaya/ Rumuodome $(\mathrm{R} / \mathrm{R})$ and Ogale $(\mathrm{O} / \mathrm{E})$ in Rivers State, Nigeria using basins fastened to a Table $2 \mathrm{M}$ above ground and $120 \mathrm{M}$ from high rise features, atmospheric rainwater after collection, was filtered into amber glass bottles before analysis. The samples were labelled, packaged in a black cellophane bag, which was taken to the laboratory for analysis.

\subsection{Extraction of petroleum hydrocarbon from rainwater samples}

The extraction of petroleum hydrocarbons from rainwater samples was carried out using the United States Environmental Protection Agency (US EPA) methodology 8015D. Precisely $200 \mathrm{~mL}$ of rainwater samples was measured out into a pre-cleaned separating funnel and mixed with $50 \mathrm{~mL}$ of dichloromethane. The mixture in the separating funnel was mechanically shaken for five minutes and allowed to separate into organic and aqueous phases; thereafter the organic phase was collected into a beaker and repeated trice with $10 \mathrm{~mL}$ dichloromethane (DCM) continuously. The corresponding organic fractions were mixed into a beaker and subsequently concentrated using a rotary concentrator $[4,18]$

\subsection{Gas Chromatography Analysis}

The petroleum hydrocarbons were quantified using Agilent GC-FID 7820A (gas chromatography equipped with a flame ionization detector). The GC-FID column infused with HP-5 fused silica capillary having dimension $(30 \mathrm{~m} \times 0.32 \mathrm{~mm} \times 0.25 \mu \mathrm{m}$ film thickness $)$ with helium gas as carrier gas at $1.75 \mathrm{~mL} / \mathrm{min}$ flow rate. Appropriate calibration was conducted using hydrocarbon standard mixture with integrated limit from $\mathrm{C}_{8} \mathrm{H}_{18}$ to $\mathrm{C}_{40} \mathrm{H}_{82}$ with five calibration-level prepared $(10-150 \mathrm{mg} / \mathrm{L})$ and injected into the gas chromatogram to obtain calibration curve of 0.99978 correspondingly. The concentrated sample extract was injected in splitless mode using DCM as standard to remove background interference to chromatogram area, as the temperature followed a stepwise process: initial temperature $\left(50^{\circ} \mathrm{C}\right.$ ) holds for $2 \mathrm{~min}$, steady increase from $10^{\circ} \mathrm{C}$ to $100^{\circ} \mathrm{C}$, holds for 2 min then ramp at $5^{\circ} \mathrm{C}$ to $250^{\circ} \mathrm{C}$ and hold for $3 \mathrm{~min}$, the final ramp from $5^{\circ} \mathrm{C}$ to $320^{\circ} \mathrm{C}$ and hold for $10 \mathrm{~min}$ [18]. The final chromatogram results were analyzed with the Agilent software (chemstation).

\subsection{Chemometric Assessment}

\subsubsection{Contamination Factor and Pollution Load Index}

The contamination factor, CF is calculated to reveal the extent of aggregate TPHs contamination in rainwater, while pollution load index entails the comparative means to assess the cumulative level of TPHs for both aliphatic and aromatic forms using reference values

$$
\mathrm{CF}=\mathrm{C}_{\mathrm{s}} / \mathrm{C}_{\mathrm{r}}
$$

Where, $\mathrm{Cs}=$ concentration of aggregate TPHs $(\mathrm{mg} / \mathrm{L})$.

$$
\mathrm{Cr}=\text { reference standards using TPHCWG [19]. }
$$


Mathematically, it is expressed as $\mathrm{CF} \leq$ lower contamination, $1<$ moderate, $3<$ Considerable, $6 \geq$ $\mathrm{CF}$, high contamination [20]. The reference standards are shown in Table 1.

The Pollution Load Index (PLI) is given as:

$$
\mathrm{PLI}=\left(\mathrm{CF}_{1} \times \mathrm{CF}_{2} \times \cdots \times \mathrm{CF}_{\mathrm{n}}\right)^{1 / \mathrm{n}}
$$

Where $\mathrm{CF}_{1}=$ contamination factor of each $\mathrm{TPH}$ aggregate assessed

$$
\mathrm{n}=\text { number of components assessed. }
$$

\subsubsection{Principal component assessment}

Principal component assessment (PCA) is a statistical tool used to identify various matrices to derive salient information about components. PCA is a data reduction technique used to find the linear combinations of variables (TPHs) leading to the formation of factors [21], gives un-rotated and rotated varimax, as rotated varimax is commonly utilized because it facilitates the best interpretation from sets of variables. The rotation is simply a process that allows a new axis to be chosen while maintaining individual components [22]. They are graded as strong $(>0.75)$, moderate $(0.75-0.50)$, and weak $(0.50-0.30)$ as done by Liu et al., [23]. PCA was determined using Microsoft Excel with XL-STAT add-ins, 2019.

\subsection{Petroleum hydrocarbon identification using molecular makers}

\subsubsection{Carbon preference index}

Carbon preference index (CPI) is the total of odd n-alkanes divided by the sum total of even n-alkanes for a range of $\mathrm{C}_{8}-\mathrm{C}_{40}$ to estimate the relative source identification of either natural or artificial contribution to petroleum hydrocarbon.

$$
\mathrm{CPI}=(\text { sum of odd } \mathrm{n}-\text { alkanes }) /(\text { sum of even } \mathrm{n}-\text { alkanes })
$$

CPI is used as a forensic indicator for petroleum source identification of TPHs. CPI values greater than 1 shows the natural contribution from biological phytoplankton plants while CPI less than 1 shows the anthropogenic (artificial) source from ubiquitous contribution [24, 25]. TPHs were aggregated into five forms to conduct $\mathrm{CPI}$ evaluation: $\mathrm{C}_{8}-\mathrm{C}_{11}, \mathrm{C}_{12}-\mathrm{C}_{17}, \mathrm{C}_{18}-\mathrm{C}_{25}, \mathrm{C}_{26}-\mathrm{C}_{33}$, and $\mathrm{C}_{34}-\mathrm{C}_{40}$.

\subsubsection{Average carbon length (ACL)}

Average carbon length is a guide used to evaluate odd n-alkanes dominance per molecule in environmental samples to form link to petrogenic plant source as a forensic tool to assess hydrocarbon contamination [26]. ACL was aggregated into five categories used in CPI assessment and calculated using equation 4 below

$$
\text { For } \mathrm{C}_{9}-\mathrm{C}_{11} ; \mathrm{ACL}=\frac{9\left(\mathrm{nC}_{9}\right)+11\left(\mathrm{nC}_{11}\right)}{\mathrm{C}_{9}+\mathrm{C}_{11}}
$$

The formula, as shown above, was conducted for other aggregates respectively. ACL values are usually constant in unpolluted rainwater samples but fluctuate as values deplete in polluted rainwater [27]. ACL was assessed for even n-alkanes in the environment to assess the anthropogenic impact in the environment. 


\subsubsection{Long-chain hydrocarbon/short-chain hydrocarbons (LHC/SHC)}

Long-chain hydrocarbons are n-alkanes above n- alkanes at $\mathrm{C}_{26}$ usually from vascular plant-based anthropogenic sources, while short-chain hydrocarbons are n-alkanes below n-alkanes at C26 from phytoplankton or algae-based sources [28].

$$
\mathrm{LHC} / \mathrm{SHC}=\left(\sum>\mathrm{nC}_{26} / \sum<\mathrm{nC}_{26}\right)
$$

They are assessed using odd and even n-alkanes. For odd n-alkanes, LHC/SHC between $0-1.00$ shows phytoplankton, $<4.00$ shows a mixture of phytoplankton and terrestrial plants, $>4.00$ indicates terrestrial plant inputs. For even n-alkanes, LHC/SHC between $0-1.00$ shows inputs from anaerobic microbial biogenic sources, $<4.00$ shows a mixture between anaerobic and anthropogenic petroleum, releases $>4.00$ shows that anthropogenic petroleum releases.

\subsubsection{Low molecular weight/ high molecular weight $(\mathrm{L} / \mathrm{H})$.}

It is the ratio of low molecular weight n-alkanes below C20, while above C20 gives the high molecular weight used to determine the n-alkanes. $\mathrm{L} / \mathrm{H}$ values close to unity (1) show natural input from marine and terrestrial biological sources, while above 1 indicates inputs from petroleum sources [29].

\subsection{5 $\mathrm{C}_{31} / \mathrm{C}_{19}$ ratio}

It is used as source identification and differentiation for TPHs in rainwater. C31 is assumed to be from terrestrial biogenic hydrocarbons, while C19 proposes marine inputs. The ratio below 0.4 reveals marine sources, while above 0.4 is from terrestrial biogenic or non-marine sources [30].

\subsubsection{Pristane/Phytane ratio}

It is the ratio of the abundance of pristane to phytane for redox conditions in the aquatic environment, based on the assumption that pristane is from oxygenated (aerobic) source degradation of planktons, while phytane is from reduction (anaerobic) source degradation of planktons by microbes. As such, Pristane/phytane ratio below unity (1) indicates oxic condition (pyrogenic source), while greater than 1 indicates anoxic (biogenic source) [31].

\subsection{Human health risk assessment}

Human health risk assessment (HHRA) is a tool used to estimate if common and potential contaminants released into the environment will adversely affect the health of humans over a long period from diverse exposure paths (inhalation, injection, dermal). According to Bharadwaj and Machibroda [32], HHRA may not prove that diseases are connected to an exposure pathway or a particular chemical agent as humans are exposed to numerous chemical agents. According to USEPA [33], it is based on characterization, risk assessment, hazard identification, receptor characterization, exposure assessment, and risk characterization.

In this study, non-carcinogenic HHRA were evaluated for adults and children for TPHs exposure via dermal and ingestion using USEPA models as shown in Equation 6 and 7 [8, 33].

Where: $\mathrm{ADI}$ is the Average daily intake $\left(\mathrm{mgkg}^{-1} \mathrm{day}^{-1}\right)$. 
$\mathrm{C}_{\mathrm{w}}$ is the concentration of petroleum hydrocarbons in water $(\mathrm{mg} / \mathrm{L})$.

2 SAF is skin adherence factor; $\left(0.12 \mathrm{mgcm}^{-2}\right.$ for adults and $0.2 \mathrm{mgcm}^{-2}$ children $)$. SA is exposed skin area: $\left(2373 \mathrm{~cm}^{2} /\right.$ day for adults and $3527 \mathrm{~cm}^{2} /$ day for children)

DAF is dermal absorption factor (unitless); ( 0.1 for adults and children)

ED is exposure duration; (25 years for adults and 6 years for children).

BW is body weight; ( $80 \mathrm{~kg}$ for adults and $15 \mathrm{~kg}$ for children).

$\mathrm{AT}$ is the average time for non - carcinogen $=\mathrm{ED} \times 365$ days

GIABS is a gastrointestinal absorption factor (unitless): (1.0 for adults and children).

THQ is target noncancer hazard quotient: (1.0 for adults and children).

$\mathrm{IR}_{\mathrm{w}}$ is ingestion rate; ( $2 \mathrm{~L}$ day ${ }^{-1}$ for adults and $1 \mathrm{~L} \mathrm{day}{ }^{-1}$ for children).

The chronic daily intake obtained from eq. (6) and eq. (7) were used to obtain the hazard index for non-carcinogenic TPHs as shown below:

$$
\mathrm{HI}=\mathrm{HQ}_{\text {dermal }}+\mathrm{HQ}_{\text {ingestion }}=\left[\left(\mathrm{CDI}_{\text {dermal }} / \mathrm{RfD}\right)\right]+\left[\left(\mathrm{CDI}_{\text {ingestion }} / \mathrm{RfD}\right)\right]
$$

Where Hazard Index (HI) is the total of Hazard quotient (HQ) from dermal and ingestion, as the acceptable limit is 1.0 [34].

Hazard quotient is the probability that an adverse health effect is imminent (unitless)

The reference dose (RfD) is shown in Table 2.

\section{Results}

Table 3 shows the mean concentration of total petroleum hydrocarbons $\left(\mathrm{C}_{8}-\mathrm{C}_{40}\right)$ assessed in Rumuodomaya/Rumuodome, Obio-Akpor LGA (R/R), and Ogale, Eleme LGA (O/E). The total of early rain, mid rain, and late rain for $\mathrm{R} / \mathrm{R}$ are $56.6551 \mathrm{mg} / \mathrm{L}, 39.5201 \mathrm{mg} / \mathrm{L}$, and $7.2283 \mathrm{mg} / \mathrm{L}$, while $\mathrm{O} / \mathrm{E}$ were $9.1217 \mathrm{mg} / \mathrm{L}, 59.4923 \mathrm{mg} / \mathrm{L}$, and $21.9825 \mathrm{mg} / \mathrm{L}$ respectively.

Table 4 shows contamination factor (CF) conducted with pollution load index (PLI). The cumulative CF were 9.953, 195.016, and 36.751 for R/R, while O/E were 41.265, 55.5908, and 21.6713 for aliphatic petroleum hydrocarbons. Aromatic petroleum hydrocarbons assessed at R/R were 304.96, 1374.307, and 225.666 for early rain, mid rain, and late rain; while that of O/E were 274.683, 1580.89, and 793.505 accordingly.

Table 5 shows principal component analysis conducted for TPHs mean concentration across the two locations. Factor analysis gave two factors for rotated varimax. R/R had cumulative variance at $29.50 \%$, the rotated varimax for $\mathrm{C}_{8}-\mathrm{C}_{40}$ ranged from -0.995 to 0.998 . O/E had cumulative variance at $77.89 \%$ with rotated varimax for $\mathrm{C}_{8}-\mathrm{C}_{40}$ ranged from -0.667 to 0.995 .

Table 6 shows the carbon preference index (CPI) conducted for five TPH aggregates $\left(\mathrm{C}_{8}-\mathrm{C}_{11}, \mathrm{C}_{12}-\right.$ $\mathrm{C}_{17}, \mathrm{C}_{18}-\mathrm{C}_{25}, \mathrm{C}_{26}-\mathrm{C}_{33}, \mathrm{C}_{34}-\mathrm{C}_{40}$ ). $\mathrm{R} / \mathrm{R}$ ranged from 0.083 to 1.630 for early, mid and late rain regiments, while $\mathrm{O} / \mathrm{E}$ ranged from 0.105 to 5.368 respectively. 
Table 7 shows the average carbon length (ACL) conducted for five TPH aggregates $\left(\mathrm{C}_{8}-\mathrm{C}_{11}, \mathrm{C}_{12}-\right.$ $\mathrm{C}_{17}, \mathrm{C}_{18}-\mathrm{C}_{25}, \mathrm{C}_{26}-\mathrm{C}_{33}, \mathrm{C}_{34}-\mathrm{C}_{40}$ ). The $\mathrm{ACL}$ values for $\mathrm{R} / \mathrm{R}$ ranged from 8.596 to 39.66 for odd and even n-alkanes derivatives, while $\mathrm{O} / \mathrm{E}$ ranged from 9.086 to 39.985 respectively.

Table 8 shows Long Chain Hydrocarbons/ Short Chain Hydrocarbons (LHC/SHC) assessed for $\mathrm{C}_{8}-$ $\mathrm{C}_{40}$. The odd n-alkanes values $\mathrm{R} / \mathrm{R}$ for early, mid and late rains were $22.268,0.722$, and 0.65 , while $\mathrm{O} / \mathrm{E}$ were $0.752,0.832$, and 4.02 . For even n-alkanes values, R/R were $220.33,1.015$, and 1.111 , while $\mathrm{O} / \mathrm{E}$ were $1.034,3.589$, and 4.881 .

Table 9 shows average daily intake (ADI) of aliphatic and aromatic petroleum hydrocarbons (PHs) for adults across early rain, mid rain and late rain respectively. For aliphatic PHs, R/R ADI (ingestion) ranged from $4.20 \mathrm{E}-05 \mathrm{mg} / \mathrm{kg} /$ day to $5.62 \mathrm{E}-02 \mathrm{mg} / \mathrm{kg} /$ day, ADI (dermal) ranged from $4.08 \mathrm{E}-05$ $\mathrm{mg} / \mathrm{kg} / \mathrm{day}$ to $5.47 \mathrm{E}-02 \mathrm{mg} / \mathrm{kg} /$ day. O/E ADI (ingestion) varies from $2.11 \mathrm{E}-05 \mathrm{mg} / \mathrm{kg} / \mathrm{day}$ to $2.82 \mathrm{E}-$ $02 \mathrm{mg} / \mathrm{kg} / \mathrm{day}$; ADI (dermal) varies from $2.06 \mathrm{E}-05 \mathrm{mg} / \mathrm{kg} /$ day to $2.74 \mathrm{E}-02 \mathrm{mg} / \mathrm{kg} /$ day. For aromatic PHs, R/R ADI (ingestion) ranged from $2.40 \mathrm{E}-04 \mathrm{mg} / \mathrm{kg} /$ day to $5.62 \mathrm{E}-02 \mathrm{mg} / \mathrm{kg} /$ day; ADI (dermal) varies from $2.34 \mathrm{E}-04 \mathrm{mg} / \mathrm{kg} /$ day to $5.47 \mathrm{E}-02 \mathrm{mg} / \mathrm{kg} /$ day. O/E ADI (ingestion) varies from 4.19E-04 $\mathrm{mg} / \mathrm{kg} /$ day to $2.82 \mathrm{E}-02 \mathrm{mg} / \mathrm{kg} /$ day, ADI (dermal) ranged from $4.088 \mathrm{E}-04 \mathrm{mg} / \mathrm{kg} /$ day to $2.74 \mathrm{E}-02$ $\mathrm{mg} / \mathrm{kg} /$ day

Table 10 shows the average daily intake (ADI) of aliphatic and aromatic petroleum hydrocarbons (PHs) for children across three rain sampling regiments (early rain, mid rain and late rain). The minimum and maximum aliphatic PHs evaluated in $\mathrm{R} / \mathrm{R}$ and $\mathrm{O} / \mathrm{E}$ are $\mathrm{ADI}$ (ingestion): 3.85E-06 $\mathrm{mg} / \mathrm{kg} / \mathrm{day}$ and $1.02 \mathrm{E}-02 \mathrm{mg} / \mathrm{kg} / \mathrm{day}$, while for ADI (dermal): $2.72 \mathrm{E}-04 \mathrm{mg} / \mathrm{kg} / \mathrm{day}$ and $7.23 \mathrm{E}-$ $01 \mathrm{mg} / \mathrm{kg} / \mathrm{day}$. For aromatic PHs, the minimum and maximum ranges are ADI (ingestion): 4.39E-05 $\mathrm{mg} / \mathrm{kg} / \mathrm{day}$ and 1.02E-02 mg/kg/day, while ADI (dermal): 3.09E-03 mg/kg/day and 7.23E-01 $\mathrm{mg} / \mathrm{kg} /$ day.

Table 11 shows the hazard quotient (HQ) of aliphatic and aromatic petroleum hydrocarbons (PHs) calculated using the reference dose (RfD) as shown in Table 2 for adults across three rain sampling regiments. Aliphatic PHs evaluated for R/R and O/E: HQ (ingested) varies from 7.02E-02E-05 to 1.30; HQ (dermal) varies from 4.12E-06 to 1.20E-01. Aromatic PHs evaluated for R/R and O/E: HQ (ingested) varies from 5.56E-03 to 2.89; HQ (dermal) varies from 1.49E-03 to 1.82 .

Table 12 shows the hazard quotient (HQ) of aliphatic and aromatic petroleum hydrocarbons (PHs) calculated using reference dose (RfD) as shown in Table 2 children across three rain-sampling regiments. Aliphatic PHs evaluated for R/R and O/E: HQ (ingested) ranged from 1.28E-05 to 2.37E01; HQ (dermal) ranged from 5.44E-05 to 1.67. Aromatic PHs were HQ (ingested) varies from 1.01E3 to $5.28 \mathrm{E}-01$; HQ (dermal) varies from 1.97 to 24.09 .

Fig 1 shows the percentage of TPHs in ambient rainwater samples in R/R and O/E sampling regiments. For R/R early rain, $\mathrm{C} 40$ had over $90.66 \%$ cumulative TPHs concentration in tandem with C39 having $7.61 \%$, while $\mathrm{C} 8-\mathrm{C} 38$ shared $1.73 \%$ accordingly. For R/R mid rain, C40 had the highest TPHs concentration of $16.58 \%$, as $\mathrm{C} 13$ and $\mathrm{C} 25$ were above $5 \%$, while C14, Phytane, C27 were within $4.12-4.47 \%$, as other TPHs aggregates ranged from $0.17-3.90 \%$. R/R late rain displayed that $\mathrm{C} 40$ was $22.662 \%$, as compared to other TPHs (C8 - C39) aggregates ranging from $0.20-5.48 \%$. O/E produced the highest percentage TPHs of C40 (20.38\%), C40 (37.42), and C36 (21.66) for the three rain sampling regiments (early rain, mid rain, and late rain), while the least percentage was present in C19 (0.55), C16 (0.05) and C37 (0.02) accordingly.

Fig 2 displays results of hazard index (HI) evaluated from HI (ingested and dermal) for aliphatic petroleum hydrocarbons (PHs) in adults and children. The cumulative sum of all HI (C6 - C8, C9 - 
C18, C19 - C32 and C33 - C40) assessed across the three rain-sampling regiments are Adults: R/R (0.038, 1.441, and 0.266), O/E (0.3561, 0.665, and 0.136), Children: R/R (0.081, 2.012 and 0.365), $\mathrm{O} / \mathrm{E}(0.472,1.016$ and 0.247$)$.

Fig 3 shows the results of hazard index (HI) calculated from HI (ingested and dermal) for aromatic petroleum hydrocarbons (PHs) in adults and children. The cumulative sum of all HI (C6 - C16, C17 - C32, C33 - C40) across early rain, mid rain, and late rain are Adults: R/R (2.054, 3.661 and 0.768), $\mathrm{O} / \mathrm{E}$ (1.031, 2.646 and 1.024), Children: R/R (24.226, 7.779 and 1.852), O/E (2.468, 20.424, 7.925).

\section{Discussion}

\subsection{Level of total petroleum hydrocarbons (TPHs) in ambient atmospheric rainwater}

Rivers State of Nigeria over the years has been embroiled in numerous cases of crude oil drillings, spills and illicit pipeline bunkering, crude oil, its fractional derivatives and gas pipeline vandalization, massive gas flares, hydrocarbon installation fire outbreaks, refinery operations, these activities are known to release toxic gaseous hydrocarbons into the atmosphere [35], related emissions from associated-petroleum industries include automobiles, coastal marine transportation, homes, and manufacturing industries utilizing diesel generators, burn-pits also account for total petroleum hydrocarbon (TPH) concentration in the atmosphere $[36,37,38]$. All the aforementioned releases in the atmosphere undergo chemical interactions, several induced or natural chemical processes such as volatilization, photo-oxidation, and biodegradation, which combine with air moisture before atmospheric rainfall deposition impacting soil and water quality [39, 40]. The surface water of the present study area is known to be laden with conjugated and straight-chain hydrocarbon [17, 41].

Results showed that ambient rainwater at Rumuodomaya/ Rumuodome (R/R) and Ogale (O/E) had elevated levels of total petroleum hydrocarbons in their combined forms (aliphatic and aromatic petroleum hydrocarbons) from early rain to late rain (Table 3). Using USEPA, [42] and TPHCWG, [19] petroleum hydrocarbons categories, there was the presence of both light and heavy carbon chains (C8 - C40). C19 - C40 indicates the presence of fuel oils; other carbon groups are due to anthropogenic activities. The highest TPH concentrations was predominant for C40 across all locations and sampling regiments and shows that higher molecular weight hydrocarbons were present. Specific range from Table 3 as carbon chain length shows TPHs value of 0.0046 of C21 TPHs (56.6551) of C40 (early rain); 0.0683 of C8 - TPHs of 6.5533 of C40 (mid rain) and 0.0142 of C34 - 1.6351 (late rain) at Rumuodomaya/ Rumuodome (R/R) while at Ogale (O/E), it ranged from 0.0500 of $\mathrm{C} 19-1.8601$ of $\mathrm{C} 40$ (early rain), 0.0342 of C8 - 22.237 (mid rain) and 0.0050 of C37 1.511 (late rain). Similar studies by Ali et al., [10] showed the presence of TPHs of River water in significant levels in three-sampling stations as they got lower concentration in October 2018, while January 2019 had a higher concentration in Al-Gharraf, Iraq, which was attributed to emission from sewage releases into rivers and municipal wastes from cities and farmland but the levels obtained were lower in comparison to the TPHs values presented here. According to Kennedy et al., [3], rainfall reveals the overall and regional atmospheric quality inclusive of all forms of emissions to the atmosphere, as similar assessment by Griffiths and Timperley [43] noted the presence of visible oil sheens on vehicle screens with particulate matter.

\subsection{Chemometric assessment}

\subsubsection{Contamination factor and pollution load index}

Contamination factor (CF) and pollution load index (PLI) were conducted on aliphatic and aromatic hydrocarbons within THGCWG [19] standards as shown in Table 4, aliphatic hydrocarbons via both 
locations, C5 - C8 were < 1, implying low contamination, while other carbon aggregates $(\mathrm{C} 9-\mathrm{C} 16$, $\mathrm{C} 17-\mathrm{C} 35$ and C36 - C40) indicates high contamination except for early and late rain of C17 - C35 and C36 - C40 at Rumuodomaya/ Rumuodome (R/R) while early and late rain of C36 - C40 at Ogale $(\mathrm{O} / \mathrm{E})$ respectively. Considering aromatic hydrocarbons, $\mathrm{C} 5-\mathrm{C} 8$ at the R/R location were below one (1) while that of $\mathrm{O} / \mathrm{E}$ early rain was considered contaminated, other carbon aggregates were highly present. Using PLI assignment, aliphatic hydrocarbons at R/R early rain were within safe background level except for mid and late rain that were above one (1), indicating high pollution of atmospheric rainwater, at Ogale $(\mathrm{O} / \mathrm{E})$, rainwater was highly polluted for all three rain periods but aromatic hydrocarbons at both $\mathrm{R} / \mathrm{R}$ and $\mathrm{O} / \mathrm{E}$ were high and polluted as they were above one (1) [44]. The contamination of water by TPH is associated with increases in particulate matter with fine particle size, high temperature, reduced dissolved oxygen, low salinity, and anaerobic reactions [45]. In addition, TPHs at higher carbon ranges are known to form oily films that prevent limited sunlight penetration thus influencing poor water quality leading to taste and odour issues over some time.

\subsubsection{Principal component analysis}

Total petroleum hydrocarbons (TPHs) were subjected to principal component analysis using rotated varimax as seen in Table 5. Rumuodomaya/ Rumuodome (R/R) had two factors with $29.50 \%$ cumulative variance, while Ogale $(\mathrm{O} / \mathrm{E})$ had $77.89 \%$ cumulative variance. There were positive and negative TPHs components across the two factors assigned. Using Liu et al., [23] at R/R, Factor 1 had moderate and strong grades except for C37 and C40, which had weak grades, while Factor 2 had moderate and strong grades, at O/E Factor 1 had predominant weak and strong grades across all TPHs components assessed except C31, while Factor 2 had strong, moderate and weak except for C16 $\mathrm{C} 27$ and $\mathrm{C} 37-\mathrm{C} 40$ that were very weak $(<0.30)$. As we can infer across both locations $(\mathrm{R} / \mathrm{R}$ and $\mathrm{O} / \mathrm{E}$ ), positive components are due to the presence of the TPH components from varying sources either petrogenic or phytogenic petroleum sources. The negative components can be due to atmospheric reactions with pyrogenic petroleum sources (combustion of carbonaceous substances), marine sea sprays, and climatic conditions [46].

\subsection{Petroleum hydrocarbon source identification}

\subsubsection{Carbon preference index}

Carbon preference index (CPI) shown in Table 6, indicated that values above one (1) were due to natural sources (terrestrial vascular floras) as compared to CPI below one (1), more in number that was due to anthropogenic and petroleum activities from the combustion of crude oil, gas flares, refinery and petrochemical plant, emission of organics from industries as a major economic activity within the area. The TPHs aggregates at Rumuodomaya/ Rumuodome (R/R) were highest at C8 C11 (1.034 and 1.005) early rain. C18 - C25 and C26 - C33 have CPI of 1.287 and 1.630 (mid-rain). C26 - C33 has a CPI of 1.288 (late-rain) but at Ogale sampling area, C26 - C33 has the highest CPI value of 1.732 (early-rain), the mid-rain highest value is for C8 - C11 (2.768) and C12 -C17 (5.368) while late-rain exhibited a CPI value of 1.490, 1.592, 1.193 and 1.728 (C8 - C11, C12 - C17, C18 C25 and C26 - C39), all these were greater than CPI value of one (1) but accounted for only $40 \%$ while values less than one (1) represent $60 \%$ hence CPI were dominated by anthropogenic origin of petroleum processing $[13,47]$.

\subsubsection{Average carbon length (ACL)}

Average carbon length (ACL) values as evaluated (Table 7) fluctuated for early rain as compared to mid rain and late rain and varied slightly for odd n-alkanes, showing there was a little anthropogenic 
contribution to the odd carbon aggregates as compared to early rain respectively [48]. ACL of TPHs aggregates shows that for odd n-alkanes minimum and maximum values were $\mathrm{C} 9$ - C11 (9.446) and C35 - C39 (38.980), C9 - C11(10.238) and C35 - C39 (36.510); C9 - C11 (10.240) and C35 - C39 (36.934) for early, mid and late rain respectively. Considering even n-alkanes, the same trend of $\mathrm{C} 8$ - C10 (9.086) and C34 - C40 (39.985); C8 - C10 (9.912) and C34 - C40 (39.985); C8 - C11 (9.553) and C34 - C40 (39.688) at Rumuodomaya/ Rumuodome (R/R) but for Ogale (O/E) area, the ACL of TPHs aggregates of odd n-alkanes were C9- C11 and C35 - C39 (9.631 and 36.647; 9.323 and 37.210; 9.362 and 35.115) for early, mid and late rain. Looking at even n-alkanes, C8 - C10 and C34 - C40 (8.596 and 39.365; 9.740 and 39.660; 9.240 and 36.727) for early, mid and late rain, again for nalkanes, similar variation as seen in odd n- alkanes were attributed to slight anthropogenic input [49]. The results of odd ACL vs CPI plots for early rain, mid rain, and late rain reveal that regression $\left(\mathrm{R}^{2}\right)$ for Rumuodomaya/ Rumuodome (R/R) were 0.4264, 0.0067, 0.0048, while O/E were 0.0103, 0.5062, 0.3358 indicating an increase in ACL as CPI values fluctuate. The regression for even-n-alkanes ACL/CPI for R/R were 0.4882, 0.0389, 0.0266, O/E were $0.0242,0.5976,0.4357$ signifying similar trends for odd-n-alkanes. This confirms that CPI assessments were influenced by both natural and anthropogenic sources.

\subsubsection{Petroleum source diagnostics}

Petroleum hydrocarbon source diagnostic ratio assessed depicted in Table 8. Average carbon length (ACL) (odd n-alkanes) has the highest value of 37.854 (early rain) and 28.248 (late rain) for Rumuodomaya/ Rumuodome (R/R) and Ogale (O/E) sampling sites. ACL (even n-alkanes) has 39.854 and 33.565 for early and mid-rain of both study areas. The two location's long-chain hydrocarbons/ short-chain hydrocarbon ratio (LHC)/SHC) of odd n-alkanes and LHC/SHC of even n-alkanes, the highest values were as follows: 22.268, 220.33 (early rain), and 4.019, 4.881 (late rain). C31/C19 showed that all three rainfall events evaluated were above 0.4 , thus shows the impact of land sources as an array of emissions from crude oil processing, industrial flue gases, power plants, automobile, and heavy-duty vehicles, flare gases [50]. In addition, elevated temperature in the soil releases volatile organic compounds while decreases in temperature usually at night activate microbial decomposition of organic matter leads to the production of petroleum hydrocarbons, influences the TPH concentration in the atmosphere. Low molecular/high molecular $(\mathrm{L} / \mathrm{H})$ weight $\mathrm{n}$ alkanes evaluated showed that the $\mathrm{L} / \mathrm{H}$ ratio was below one (1), suggesting impact from phytogenic and pyrogenic sources. Long-chain hydrocarbons/short-chain hydrocarbons (LHC/SHC) assessed for odd and even n-alkanes reveals that at $\mathrm{R} / \mathrm{R}$ early rain and $\mathrm{O} / \mathrm{E}$ late rain were above one (1), indicating terrestrial floral sources, while below 1 is due to phytoplankton sources. LHC/SHC (even n-alkanes) were all above one (1), thus confirming all were from petroleum sources. Cumulative CPI assessed were below one (1) from a pyrogenic source. Cumulative average carbon length (ACL) (odd and even $\mathrm{n}$ - alkanes) showed fluctuating values confirming impact from anthropogenic sources. The plot of cumulative odd ACL against cumulative CPI via the influence of the three rain regimens showed that regression, $\mathrm{R}^{2}$ were 0.9454 and 0.0607 at $\mathrm{R} / \mathrm{R}$ and $\mathrm{O} / \mathrm{E}$, while even ACL versus CPI plot gave regression, $\mathrm{R}^{2}=0.9594$ and 0.291 respectively. Therefore, we can infer that petroleum hydrocarbon in atmospheric rainwater of the study area was predominantly from anthropogenic sources. The ratio of pristane/phytane exceeded one (1) for R/R early rain and late rain in relation to $\mathrm{O} / \mathrm{E}$ mid rain indicating biogenic (aerobic) sources, as anaerobic indices are possible for values less than one (1) for R/R mid rain and $\mathrm{O} / \mathrm{E}$ early and late rains [51]. In addition, different assessment has shown that pristane/phytane less than 0.8 implies saline to the hypersaline condition due to extreme evaporation and carbonaceous deposition, whereas pristane/phytane above 3 is due to oxygenated to nonoxygenated degradation of planktons from anaerobic organisms [52]. Pristane and phytane are biproducts of chlorophyll in the aquatic environment, pristane are produced from the breakdown of zooplankton and phytoplankton (algae) in an oxygenated aquatic environment to form lipids, whereas 
phytanes are from anaerobic degradation of aquatic planktons by microbial organisms (cyanobacteria) [53]

\subsection{Risk assessment}

The average daily intake (ADI) of aliphatic and aromatic petroleum hydrocarbons aggregates was assessed for ambient atmospheric rainwater from Rumuodomaya/Rumuodome (R/R) and Ogale (O/E). Two exposure pathways were calculated using ingestion (oral) and dermal (skin contact) to assess the average daily intake (ADI) of rainwater for adults and children as depicted in Tables 9 and 10, but from Table 9, aliphatic PHs of C33 - C40 were exposed to adult through dermal and ingestion by $5.47 \times 10^{-02}$ and $5.62 \times 10^{-02}$ via consumption of early rain from Rumuodomaya/Rumuodome, the same for aromatic PHs of C33 - C40 $\left(5.47 \times 10^{-2}\right.$ and $\left.5.62 \times 10^{-2}\right)$. At Ogale, the same adults are more at risk of aliphatic PHs of C19 - C32 and C33 - C40 $\left(2.07 \times 10^{-2}, 2.02 \times 10^{-2} ; 2.82 \times 10^{-2}\right.$, and $2.74 \times 10^{-2}$ ) through ingestion of or dermal contact with mid-rain while they are highly exposed to $\mathrm{C} 17$ - C32 and C33 - C40 by $2.50 \times 10^{-2} ; 2.04 \times 10^{-2} ; 2.82 \times 10^{-2}$ and $2.74 \times 10^{-2}$ on contact with mid-rain through ingestion and dermal pathway and to $\mathrm{C} 17$ - C32 (the same exposure route) risk value of $1.21 \times 10^{-2}$ and $1.18 \times 10^{-2}$ (late rain). Non-carcinogenic risk assessment for adults and children evaluated having obtained hazard quotient (HQ) for exposed pathways as shown in Tables 11 and 12. Preliminary assessment of ADI and subsequent evaluation of HQ shows that children had elevated values compared to adults. Hazard index (HI) as shown in Fig 1 for aliphatic petroleum hydrocarbons reveals that at $\mathrm{R} / \mathrm{R}$, mid rain for adults and children were above one (1), thus there is an inherent health risk. At $\mathrm{O} / \mathrm{E}$, mid rain for children was above one (1), as compared to adults. The hazard index for aromatic petroleum hydrocarbons shown in Fig 2 shows that all locations including the rain period were above one (1). Risk-based mapping using carbon ranges were proposed by MADEP [54, 55] and TPHCWG [56] to assess the health-based risk over a period for all age grade, sex orientation, diet, family traits, lifestyle and current state of health to derive salient points for regulatory consideration and action plan models. The analysed HI values reveals that ingestion of TPHs contaminated rainwater by both adult and children leads to bioaccumulation resulting in disruption of biochemical and physiological activities in the human body causing negative health outcomes usually after a short period [11].

In the atmosphere, where free chloride ions exist in the presence of ultra-violet radiation and hightemperature conditions permit (Table 13), combines with aliphatic petroleum hydrocarbons (aerosols) to form toxic polychlorinated $-\mathrm{n}$-alkanes (PCAs), and polychlorinated biphenyls (PCBs). These subsequently dissolved in rainwater impacting water quality as when ingested over a period of time can cause detrimental health issues such as liver and kidney dysfunctions, dermatitis, dizziness, and severe headaches [17]. In addition, PAHs photochemical reactions form diones, nitro-PAHs, dinitroPAHs, and other PAHs components known to cause carcinogenic and mutagenic effects and resulting in human health crises such as bone suppression and decreased blood cell production with reproductive complications [57]

TPHs ingestion via atmospheric rainwater has been associated with headaches, fatigue, nausea, diarrhoea, and irritation of gastrointestinal tracts over a long period [58]. Renal disorder, digestive disruption, and interstitial oedema are also negative health outcomes associated with consumption of contaminated rainwater [59]. Dermal contact with contaminated rainwater sources can cause skin inflammation and rashes, dermatitis, blisters, eye irritation, and degreasing burns where been reported by persons during bathing periods in amazon, Ecuador [60]. In children, the presence of dandruff and psoriasis has been attributed to TPHs [61]. Petroleum hydrocarbon represents all aliphatic and aromatic petroleum formulations. Aliphatic petroleum hydrocarbon is known to cause neurological disorders, cancer of the mouth, stomach, and uterine due to the presence of oil pollution [60]. 
Aromatic petroleum hydrocarbons in the form of benzene, toluene, polycyclic aromatic hydrocarbons cause haematological, immunological, neurological, gastrointestinal disorders inclusive of possible death associated with these contaminants. Having assessed these possible health effects, children are most at risk as reports by Steven [60], give worrisome reports that need adequate attention to mitigates these issues in the long run.

\section{Conclusion}

The present study assessed total petroleum hydrocarbons (TPHs) in rainwater sampled via three regiments (early rain, mid rain, and late rain) at Rumuodomaya/ Rumuodome and Ogale in Rivers State, Nigeria. The TPH concentration at Rumuodomaya/ Rumuodome decreased from early rain to late rain, while Ogale had a high concentration at mid rain, least for late rain that reveals the rainwater were relatively contaminated and unsafe for human consumption from crude oil and gas processing releases into the atmosphere and subsequently as rainwater. Chemometric assessment using total petroleum hydrocarbon criteria working group standards showed that both aliphatic and aromatic petroleum was relatively high. TPHs source identification showed that carbon preference index and average carbon length gave correlation, which implies that contaminations were due to anthropogenic sources, probably hydrocarbon been the major economic activity in the area. A risk assessment conducted showed that hazard index was above one (1) for aromatic petroleum hydrocarbons compared to aliphatic petroleum hydrocarbon that had varying levels. The pollution levels show that children were more at risk from continuous oral and dermal exposure to TPHs in rainwater. Government agencies with assistance from oil and gas stakeholders can set up a monitoring stations for air, soil, and water contamination sources to assist in the development of a cost-effective approach and remediation action plan to avert possible health issues in the future.

\section{Acknowledgement}

The authors wish to thank BGI Laboratories Rumukwurushi, Rivers State, Nigeria for their technical assistance during the research process.

\section{Data Information}

We have no special data information to declare, every data pertaining to the work is as presented in the results

\section{Financial Assistance}

We did not receive any financial assistance for this research work

\section{Declaration of Competing Interest}

The authors declared no conflict of interest.

Availability of Data and Materials

All the data generated in the work are included as tables and figures

\section{Code Availability}

Not Applicable

\section{Ethics Approval}


Not Applicable

2 Consent to Participate

3 Not Applicable

\section{Consent for Publication}

5 All the authors agreed to submit the manuscript to Scientific Report for consideration and possible 6 publication

\section{Research Funding}

$9 \quad$ None declared

\section{Conflict of Interest}

The authors declare no conflict of interest regarding this article.

\section{3}

\section{References}

1. NBS. Annual Abstract of Statistics. National Bureau of Statistics. https://www.nigerianstat.gov.ng. (2010)

2. Reijers, T. J. A, Petters S. W, Nwajide, C. S. The Niger Delta Basin. In Selected Chapters on Sedimentary Geology and Stratigraphy in Nigeria. SPDC, Nigeria. 103 117. (1996)

3. Kennedy, P., Allen, G and Wilson, N. The management of hydrocarbons in stormwater runoff: a literature review. Prepared by Golder Associates (NZ) Limited for Auckland Council. Auckland Council technical report, TR 2016/010. ISBN 978-0-9941350-9-4. (2016)

4. Bolade, O.P., Adeniyi, K.O., Williams, A.B., Benson, N.U. Remediation and Optimization of petroleum hydrocarbons degradation in contaminated water using alkaline persulphate. Journal of Environmental Chemical Engineering, 105801 : https://doi.org/10.1016/j/jece.2021.105801. (2021).

5. Tony GT, Fisk AT, Westmore JB, Muir DCG. Environmental Chemistry and Toxicology of polychlorinated n-alkanes. Rev Environ Contam Toxicol 158: 53 - 128. (1998)

6. Environment Canada. Priority substances program. CEPA assessment report, chlorinated parafins. Commercial Chemicals Branch, Peterborough. (1993) 
7. Ogoko, E.C., Kelle, H.I. Anions, Total Petroleum Hydrocarbons and Aromatic Hydrocarbons in Soils of Aba Dumpsites. British Journal of Applied Science \& Technology 14(1): 1-8. http://doi.org/10.9734/BJAST/2016/22084. (2016).

8. HIDOH. Collection and Use of Total Petroleum Hydrocarbon Data for the Risk-Based Evaluation of Petroleum Releases, Example Case Studies (draft January 2018): R. Brewer, M. Nagaiah and R. Keller, authors. Hawai 'i Department of Health, Hazard Evaluation and Emergency Response Office. Honolulu, Hawaii. (2018)

9. ATSDR. Agency for Toxic Substances \& Disease Registry. Toxic substances portal - Total petroleum hydrocarbons (TPH). Toxicological profile for total petroleum hydrocarbons. https:// www.atsdr.cdc.gov/ToxProfiles/TP.asp?id=424\&tid=75\#bookmark10. [Accessed 12 Feb 2021] (2018)

10. Ali, A.S., Al_Khafaji B.Y., Al-Gezi, H.R. Comparative study of hydrocarbon pollution before and after rainfall in Al-Gharraf River in Thi-Qar province - Iraq. IOP Conf. Series: Journal of Physics. 1279: 1-13. http://doi.org/10.1088/1742-6596/1279/1/012029. (2019).

11. Kuppusamy S., Maddela N.R. Megharaj M., Venkateswarlu K. Impact of Total Petroleum Hydrocarbons on human health. In: Total Petroleum Hydrocarbobs. Springer, Cham. ISBN:978-3-030-24035-6. https://doi.org/10.1007/978-3-030-24035-6_6. (2020).

12. Faustorilla, M.V., Chen, Z., Dharmarajan R., Naidu, R. Determination of Total Petroleum Hydrocarbons in Australian Groundwater Through the Improvised Gas ChromatographyFlame Ionization Detection Technique. Journal of Chromatographic Science. 55(8): 775-783 http://doi.org/10.1093/chromsci/bmx038.2017. (2017).

13. Omokpariola, J.O. Omokpariola D.O. and Omokpariola, E.C.O. Risk Assessment of Polycyclic Aromatic Hydrocarbons and Total Petroleum Hydrocarbons in Oilfield Produced Water and Sea Water at Gulf of Guinea Oilfield, Nigeria. Advanced Journal of Chemistry-Section B, 3(1), 68-85. CC10.22034/ajcb.2021.121909 . (2021).

14. Akinola, J.O, Olawusi-Peters, O.O, Apkambang, V.O.E. Human health risk assessment of TPHs in brackish water prawn (Nematopalaemon hastatus, Aurivillus, 1898). Heliyon 6: 1-6 https://doi.org/10.10.1016/j.heliyon.2020.e03234. (2020).

15. Oyibo, J.N., Wegwu, M.O., Uwakwe, A.A., Osuoh, J.O. Analysis of total petroleum hydrocarbons, polycyclic aromatic hydrocarbons and risk assessment of heavy metals in some selected finfishes at Forcados Terminal, Delta State, Nigeria. Environmental Nanotechnolological Monitoring Management $\quad 9$ 128-135. https://doi.org/10.1016/j.enmm.2017.11.002 . (2018).

16. Anyakora C. A, Coker H. Determination of polynuclear aromatic hydrocarbons (PAHs) in selected water bodies in Niger Delta. African J. Biot. 5 (21): 2024 - 2031.

17. Nduka J.K.C., Orisakwe O.E. Water quality issues in the Niger Delta of Nigeria: Polyaromatic and straight chain hydrocarbons in some selected surface waters. Water Quality Exposure Health. 2: 65-74. http://doi.10.1007/s12403-010-0024-5. (2010a). 
18. WSDE. (1997). Analytical Methods for Petroleum Hydrocarbons, Department of Ecology Publications Distribution Centre, Olympia, Wash, Washington State Department of Ecology USA,

19. THQCWG. Hydrocarbon Spills into Water Public Health Risk Assessment (PHRA). Ruth McDermott, Keith Ian Quintyne, Regina Kiernan, Mary O Mahony and Ina Kelly. Based on an original document written by Tessa Greally. (Date: 6th December 2019). (2019).

20. Enyoh CE, Verla AW, Egejuru NJ. pH Variations and Chemometric Assessment of Borehole Water in Orji, Owerri Imo State, Nigeria. J Environ Anal Chem; 5(238): 1-9. http://doi:10.4172/2380-2391.1000238. (2018)

21. Ravindra, K. Sokhi R. Van-Grieken, R. Atmospheric polyaromatic hydrocarbons: source attribution, emission and regulation. Atmospheric Environment 42:2895-2921. https://doi.org/10.1016/j.atmosenv.2007.12.010 • (2008).

22. Yang, F. Zhai, Y.B. Chen, L. Li C.T. Zeng G.M. The seasonal changes and spatial trends of particle-associated polycylic aromatic hydrocarbons in the summer and autmn in Changsha City. Atmos. Res., 96:122-130 http://dx.doi.org/10.1016/j.atmosres.2009.12.004 • (2010)

23. Liu, C.W., Lin, K.H., Kuo, Y.M. Application of factor analysis in the assessment of groundwater quality in a black foot disease area in Taiwan. Science Total Environment. 313: 77-89. https://doi.org/10.1016/S0048-9697(02)00683-6 . (2003).

24. Mudge. S.M. Methods in Environmental Forensics. CRC Press. 43-112. ISBN:13-978 08493 5007 8. (2009).

25. Murphy, B.L. Morrison. R.D. Introduction to Environmental Forensics. Elsevier Academic Press Publication. 311-454 ISBN: 13 978-0-12-369522-2. (2007).

26. Wang, M. Zhang, W. Hou, J. Is average chain length of plant lipids a potential proxy for vegetation, environment and climate changes? Biogeosciences Discussions. 12: 5477-5501. http://dx.doi.org/ 10.5194/bgd-12-5477-2015. (2015).

27. Jeng W.L. Higher plant n-alkane average chain length as an indicator of petrogenic hydrocarbon contamination in marine sediments. Marine Chemistry. 102(3-4):242-251. https://doi.org/10.1016/j.marchem.2006.05.001 • (2006).

28. Adeniji, A.O., Okoh, O. Okoh A.I. Petroleum Hydrocarbon Fingerprints of Water and Sediment Samples of Buffalo River Estuary in the Eastern Cape Province, South Africa. Journal of Analytical Methods in Chemistry. 2017: 1-13 https://doi.org/10.1155/2017/2629365. (2017).

29. Fagbote O. E., Olanipekun. E. O. Characterization and sources of aliphatic hydrocarbons of the sediments of River Oluwa at Agbabu Bitumen deposit area, Western Nigeria," Journal of Scientific Research and Reports. 2(1):228- 248. https://doi.org/10.9734/JSRR/2013/3063. (2013).

30. Ahmed, O. E. Mahmoud, S. A. Mousa A. E. M. Aliphatic and poly-aromatic hydrocarbons pollution at the drainage basin of Suez Oil Refinery Company. Current Science International. (1):27-44. (2015).

31. Jamaluddin, J., Fuqi, C., Syamsuddin, E. and Umar, E.P. Interpretation of paleodepositional environment using biomarkers and carbon isotope ( $\delta 13 \mathrm{C})$ in Talang Akar Formation, South Sumatra Basin, Indonesia. IOP Conference Series: Earth and Environmental Science 279 (012024): 1-9.http://doi.org/10.1088/1755-1315/279/1/012024 . (2019). 
32. Bharadwaj L, Machibroda, R. Human Health Risk Assessment Approach for Urban Park Development Arh Hig Rada Toksikol. 59:213-221 http://dio.org/10.2478/10004-1254-592008-1882 . (2008).

33. USEPA. Provisional Peer-Reviewed Toxicity Values for Complex Mixtures of Aliphatic and Aromatic Hydrocarbons; U.S. Environmental Protection Agency, Superfund Health Risk Technical Support Centre, National Centre for Environmental Assessment, Office of Research and Development: Washington, DC, USA. (2009).

34. Pinedo, J., Ibáñez, R. Irabien Á. A comparison of models for assessing human risks of petroleum hydrocarbons in polluted soils. Environmental Modelling \& Software. 55: 61-69 http://dx.doi.org/10.1016/j.envsoft.2014.01.022 . (2014).

35. Kalagbor, I.A., Dibofori-Orji, A.N. Ekpete O.A. Exposure to Heavy Metals in Soot Samples and Cancer Risk Assessment in Port Harcourt, Nigeria. Journal of Health and Pollution 9 (24): 191211. http://doi.org/10.5696/2156-9614-9.24.191211. (2019).

36. Nduka, J.K. Amuka, J.O. Onwuka, J.C. Udowelle, N.A. Orisakwe, O.E. Human health risk assessment of lead, manganese and copper from scrapped car paint dust from automobile workshops in Nigeria. Environmental Science Pollution Research. 3 (20): 20341-20349, https://doi.org/10.1007/s11356-016-7219-7. (2016).

37. Nduka, J.K. Kelle, H.I. Amuka, J.O. Health risk assessment of cadmium, chromium and nickel from car paint dust from automobile at auto-panel workshops in Nigeria. Toxicology Report. 6: 449-456, https://doi.org/10.1016/j.toxrep.2019.05.007. (2019).

38. Bona, C., Rezende, I., Santos, G., Souza, L. Effect of soil contaminated by diesel oil on the germination of seeds and the growth of Schinus terebinthifolius Raddi (Anacardiaceae) seedlings; Brazilian Archives of Biology and Technology. 54: 1379-1387. (2011).

39. Nduka, J.K., Orisakwe, O.E. Precipitation Chemistry and Occurrence of Acid Rain over the OilProducing Niger Delta Region of Nigeria. The Scientific World JOURNAL. 10: 528-534 http://10.1100/tsw.2010.61. (2010b).

40. Nduka, J.K.C., Orisakwe, O.E., Ezenweke, L.O., Ezenwa, T.E. Chendo, M.N., Ezeabasili, N.G. Acid Rain Phenomenon in Niger Delta Region of Nigeria: Economic, Biodiversity, and Public Health Concern. The Scientific World JOURNAL8: 811-818. http://10.1100/tsw.2008.47 . (2008).

41. Orisakwe OE, Nduka JK. Assessment of pollution profiles of some surface water in Niger Delta. Lambert Academic Publishers. Saarbrucken, Germany. ISBN:978-3-8383-8123-7. 2011)

42. USEPA. Regional Screening Levels: U.S. Environmental Protection Agency, Superfund, May 2016. (2016).

43. Griffiths G, Timperley M. Auckland City stormwater - A summary of NIWA and other relevant studies. NIWA Client Report AKL2005-007. Prepared for Auckland City Council and Metro Water Limited. Auckland: NIWA. (2005).

44. Liu, W.H., Zhao, J.Z., Ouyang, Z.Y., Soderlund, L., Liu, G.H. Impacts of sewage irrigation on heavy metal distribution and contamination in Beijing, China. Environment International. 31:805 -812. http://dx.doi.org/10.1016/j.envint.2005.05.042 . (2005). 
45. Van Dam, R.A., Camilleri, C., Turley, C. Preliminary assessment of petroleum hydrocarbons in water and sediment at Yellow Water, Kakadu National Park Wetland Protection and Management. Environmental Research Institute of the Supervising Scientist (ERISS). Locked Bag 2, Jabiru, NT, 0886. Internal Report: 283. (1998).

46. Omokpariola, D.O. Nduka, J.K. Omokpariola P.L. Omokpariola, E.C.O. Ionic composition of rainwater from different sampling surfaces across selected locations in Rivers, Nigeria. World Scientific News. 150 (132-147). http://www.worldscientificnews.com/ (2020).

47. De-Abreu-Mota, M. A., de Moura Barboza, C. A., B'ıcego, M. C., Martins, C. C. Sedimentary biomarkers along a contamination gradient in a human-impacted sub-estuary in Southern Brazil: a multi-parameter approach based on spatial and seasonal variability. Chemosphere.103:156-163. https://doi.org/10.1016/j.chemosphere.2013.11.052 . (2014).

48. Al-Baldawi, I. A. Abdullah, S. R. S. Anuar, N. Suja, F. Mushrifah I. Phytodegradation of total petroleum hydrocarbon (TPH) in diesel-contaminated water using Scirpus grossus. Ecological Engineering. 74:463-473. https://doi.org/10.1016/j.ecoleng.2014.11.007 . (2015).

49. Mohd-Ali, S.A., Tair, R., Yang, S.Z., Mohd-Ali, M. Petroleum hydrocarbon in surface sediment from coastal area of Putatanand Papar, Sabah. Malaysian Journal of Analytical Sciences. 17(2): 286-290. (2013).

50. Zhang Z., Yan, X., Gao, F., Thai, P., Wang, H., Chen, D., Zhou, L., Gong, D., Li, Q., Morawska, L., Wang, B. Emission and health risk assessment of volatile organic compounds in various processes of a petroleum refinery in the Pearl River Delta, China. Environmental Pollution. 238:452-461. http://dx.doi.org/10.1016/j.envpol.2018.03.054 . (2018)

51. Al-Hejujem M.M. Al-saad, H.T, Hussain, N.A. Total Petroleum Hydrocarbons (TPHs), n-alkanes and Polynuclear Aromatic Hydrocarbons (PAHs) in Sediments of Shatt Al-Arab River - part 2. Global Journal of Biology, Agriculture and Health Sciences 4(1): 95-100. (2015).

52. Mc Kirdy, K.D. and Powell, T. G. Relationship between Ratio of Pristane to Phytane, Crude Oil Composition and Geological Environment in Australia. Nature Physical Science. 243 (124): 37-39. http://doi.org/10.1038/physci243037a0. ISSN 2058-1106. (1973).

53. Silva, R.A.; Grossi, V. and Alvarez, H.M. Biodegradation of phytane $(2,6,10,14-$ tetramethylhexadecane) and accumulation of related isoprenoid wax esters by Mycobacterium ratisbonense strain SD4 under nitrogen-starved conditions. FEMS Microbiology Letters. 272(2):220-228. https://doi.org/10.1111/j.1574-6968.2007.00770.x. (2017).

54. MADEP. Updated Petroleum Hydrocarbon Fraction Toxicity Values for the VPH/EPH/EPH Methodology; Massachusetts Department of Environmental Protection, Bureau of Waste Site Clean-up: Boston, MA, USA. (2003).

55. MADEP. MCP Numerical Standards Development Spreadsheets: Massachusetts. Department of Environmental Protection, Bureau of Waste Site Clean-up. (Updated June 2014). (2014).

56. TPHCWG. Human health risk-based evaluation of petroleum release sites: implementing the working group approach. Amherst, MA, Amherst Scientific Publishers (Total Petroleum Hydrocarbon Criteria Working Group Series, Vol. 5). (1999)

57. WHO Guidelines for drinking-water quality 2017; Fourth edition incorporating the first addendum, Geneva, Switzerland: World Health Organization; 
http://apps.who.int/iris/bitstream/10665/ 254637/1/9789241549950-eng.pdf?ua=1. [Assessed Feb 2, 2021]. (2017)

58. Orta-Martinez, M., Rosell-Mele, A., Cartro-Sabate, M., O’Callaghan-Gordo, C., MoraledaCibrian, N., Mayor, P. First evidences of Amazonian wildlife feeding on petroleumcontaminated soils: a new exposure route to petrogenic compounds. Environmental Resources 160:514-517 https://doi.org/10.1016/j.envres.2017.10.009 . (2018)

59. Fowzia A., Fakhruddin, A.N.M. A Review on Environmental Contamination of Petroleum Hydrocarbons and its Biodegradation. International Journal of Environmental Science National Research. 11(3): 555811. http://10.19080/IJESNR.2018.11.555811. (2018).

60. Steven D. Amazon Watch Blog - Chevron's "Amazon Chernobyl” in Ecuador: the real irrefutable truths about the company's toxic dumping and fraud. https://chevroninecuador.org/news-andmultimedia/2015/0527-chevrons-amazon-chernobyl-in-ecuador-the-real-irrefutable-truths. [Accessed March, 14 2021]. (2015).

61. Olof, L., Jonas, P. Oil contamination in Ogoni land, Niger Delta. American. Biology. 42:685701. (2013) 
Table 1: Reference standards for petroleum hydrocarbons

\begin{tabular}{ll}
\hline Aliphatic & Reference values $(\mathrm{mg} / \mathrm{L})$ \\
\hline C5 - C8 & 3 \\
C9 - C16 & 0.065 \\
C17-C35 & 1 \\
C36-C40 & 10 \\
\hline Aromatic & Reference values $(\mathrm{mg} / \mathrm{L})$ \\
\hline C5 - C8 & 0.13 \\
C8 - C16 & 0.025 \\
C17 - C35 & 0.02 \\
C36-C40 & 0.2 \\
\hline
\end{tabular}

TPHCWG, 2019

Table 2: Reference dose of total petroleum hydrocarbons (TPHs)

\begin{tabular}{l|cccc}
\hline \multicolumn{1}{l}{ Aliphatic } & Dermal & Source & Ingestion & Source \\
\hline Low Carbon range $(\mathrm{C} 5-\mathrm{C} 8)$ & 5 & TPHCWG, 2019 & 0.04 & CEPA, 2009 \\
Medium Carbon range $(\mathrm{C} 9-\mathrm{C} 18)$ & 0.1 & TPHCWG, 2019 & 0.01 & USEPA, 2016 \\
High Carbon range $(\mathrm{C} 19-\mathrm{C} 32)$ & 2 & TPHCWG, 2019 & 3 & USEPA, 2016 \\
High Carbon range $(\mathrm{C} 33-\mathrm{C} 40)$ & 20 & TPHCWG, 2019 & 30 & PPRTV \\
& & & & \\
\hline Aromatic & Dermal & Source & Ingestion & Source \\
\hline Low Carbon range $(\mathrm{C6}-\mathrm{C} 16)$ & 0.2 & TPHCWG, 2019 & 0.004 & USEPA, 2016 \\
Medium carbon range $(\mathrm{C} 17-\mathrm{C} 32)$ & 0.04 & TPHCWG, 2019 & 0.04 & USEPA, 2016 \\
High carbon range $(\mathrm{C} 33-\mathrm{C} 40)$ & 0.03 & TPHCWG, 2019 & 0.4 & HEAST
\end{tabular}

TPHCWG: Total Petroleum Hydrocarbon Criteria Working Group, PPRTV: Provisional Peer-Reviewed Toxicity Value, HEAST: Health Effect Assessment Summary Table. 
Table 3: Mean concentration of TPHs determined in rainwater samples

\begin{tabular}{|c|c|c|c|c|c|c|}
\hline \multirow[b]{2}{*}{ TPHS } & \multicolumn{3}{|c|}{$\begin{array}{l}\text { Rumuodomaya/Rumuodome, Obio- } \\
\text { Akpor Local Government Area } \\
\text { (LGA) }\end{array}$} & \multicolumn{3}{|c|}{$\begin{array}{l}\text { Ogale, Eleme Local Government } \\
\text { Area }\end{array}$} \\
\hline & Early Rain & Mid Rain & Late Rain & Early Rain & Mid Rain & Late Rain \\
\hline $\mathrm{C} 8$ & 0.0419 & 0.0683 & 0.1138 & 0.6713 & 0.0342 & 0.0211 \\
\hline $\mathrm{C} 9$ & 0.0948 & 0.9477 & 0.1848 & 0.7001 & 0.7284 & 0.0827 \\
\hline $\mathrm{C} 10$ & 0.0498 & 1.4817 & 0.3963 & 0.2850 & 0.2290 & 0.0344 \\
\hline C11 & 0.0272 & 1.5403 & 0.3017 & 0.3225 & 0.1403 & 0.0183 \\
\hline $\mathrm{C} 12$ & 0.0294 & 1.3199 & 0.3533 & 0.3214 & 0.2550 & 0.0179 \\
\hline $\mathrm{C} 13$ & 0.0121 & 2.2727 & 0.2963 & 0.1228 & 0.1380 & 0.0159 \\
\hline $\mathrm{C} 14$ & 0.0245 & 1.6737 & 0.1360 & 0.2343 & 0.0664 & 0.0506 \\
\hline C15 & 0.0098 & 0.8761 & 0.3332 & 0.3279 & 0.0571 & 0.0365 \\
\hline C16 & 0.0161 & 1.3738 & 0.2074 & 0.1304 & 0.0291 & 0.1412 \\
\hline C17 & 0.0090 & 0.4859 & 0.0463 & 0.1998 & 1.6863 & 0.2815 \\
\hline Pristane & 0.0120 & 0.8945 & 0.2664 & 0.1118 & 2.4970 & 0.0775 \\
\hline C18 & 0.0208 & 1.0053 & 0.1172 & 0.4235 & 2.5371 & 0.4606 \\
\hline Phytane & 0.0086 & 1.6272 & 0.1383 & 0.2979 & 1.8832 & 0.2612 \\
\hline C19 & 0.0122 & 1.3125 & 0.1710 & 0.0500 & 1.3617 & 0.5663 \\
\hline $\mathrm{C} 20$ & 0.0233 & 0.7409 & 0.2457 & 0.0513 & 2.2847 & 0.5956 \\
\hline $\mathrm{C} 21$ & 0.0046 & 0.9557 & 0.1274 & 0.1906 & 1.6645 & 0.1990 \\
\hline $\mathrm{C} 22$ & 0.0193 & 1.3712 & 0.2059 & 0.2061 & 1.0623 & 0.2579 \\
\hline $\mathrm{C} 23$ & 0.0280 & 1.2082 & 0.1362 & 0.1010 & 2.8227 & 0.6480 \\
\hline
\end{tabular}




\begin{tabular}{llll|lll} 
C24 & 0.0100 & 1.1233 & 0.2084 & 0.2274 & 1.9995 & 0.5236 \\
C25 & 0.0290 & 1.9830 & 0.1881 & 0.3157 & 0.8231 & 0.7794 \\
C26 & 0.0222 & 1.1604 & 0.1231 & 0.1463 & 2.2010 & 0.9508 \\
C27 & 0.0050 & 1.7674 & 0.1348 & 0.2968 & 0.9965 & 1.1551 \\
C28 & 0.0198 & 0.4857 & 0.1242 & 0.0924 & 1.5103 & 0.9357 \\
C29 & 0.0122 & 0.6331 & 0.1461 & 0.2119 & 0.2411 & 0.7200 \\
C30 & 0.0061 & 0.4414 & 0.0757 & 0.0746 & 1.1923 & 0.4986 \\
C31 & 0.0093 & 1.2852 & 0.1376 & 0.0735 & 1.0964 & 2.4430 \\
C32 & 0.0093 & 0.3896 & 0.0958 & 0.0866 & 1.4583 & 1.0476 \\
C33 & 0.0131 & 0.3519 & 0.1211 & 0.1106 & 1.1497 & 1.6139 \\
C34 & 0.0047 & 0.2803 & 0.0142 & 0.1100 & 0.7749 & 0.5486 \\
C35 & 0.0187 & 0.5108 & 0.1129 & 0.2260 & 0.9056 & 0.6931 \\
C36 & 0.0095 & 0.7341 & 0.0997 & 0.1129 & 0.6614 & 4.7606 \\
C37 & 0.0057 & 0.113 & 0.0950 & 0.1438 & 0.7364 & 0.0050 \\
C38 & 0.3627 & 0.2630 & 0.0367 & 0.1541 & 0.4592 & 0.0113 \\
C39 & 4.3094 & 0.2877 & 0.1026 & 0.1367 & 1.2048 & 0.0180 \\
C40 & 51.3652 & 6.5533 & 1.6351 & 1.8601 & 22.2371 & 1.5107 \\
\hline TOTAL & 56.6551 & 39.5201 & 7.2283 & 9.1271 & 59.4323 & 21.9825 \\
\hline
\end{tabular}

Table 4: Contamination Factor and Pollution Load Index of Petroleum hydrocarbons aggregates 


\begin{tabular}{|c|c|c|c|c|c|c|c|}
\hline & & \multicolumn{3}{|c|}{$\begin{array}{l}\text { Rumuodomaya/Rumuodome, Obio- } \\
\text { Akpor LGA }\end{array}$} & \multicolumn{3}{|c|}{ Ogale, Eleme LGA } \\
\hline & & Early Rain & Mid Rain & Late Rain & Early Rain & Mid Rain & Late Rain \\
\hline \multirow{7}{*}{$\begin{array}{l}\text { Aliphatic } \\
\text { Hydrocarbons }\end{array}$} & C5-C8 & 0.0140 & 0.0228 & 0.0379 & 0.2238 & 0.0114 & 0.007 \\
\hline & C9-C16 & 4.0569 & 176.706 & 33.9846 & 37.6062 & 25.28154 & 6.115385 \\
\hline & C17-C35 & 0.2766 & 17.4918 & 2.5317 & 3.1941 & 27.768 & 14.9183 \\
\hline & C36-C40 & 5.6053 & 0.79511 & 0.1969 & 0.2408 & 2.52989 & 0.63056 \\
\hline & Mean CF & 2.4882 & 48.7540 & 9.1878 & 10.316 & 13.89771 & 5.417819 \\
\hline & $\Sigma \mathrm{CF}$ & 9.9527 & 195.016 & 36.751 & 41.2648 & 55.5908 & 21.67128 \\
\hline & PLI & 0.5444 & 2.7350 & 0.8954 & 1.5949 & 2.1211 & 0.79755 \\
\hline \multirow{7}{*}{$\begin{array}{l}\text { Aromatic } \\
\text { Hydrocarbons }\end{array}$} & C5-C8 & 0.3223 & 0.5254 & 0.8754 & 5.1638 & 0.2630 & 0.162308 \\
\hline & C9-C16 & 10.548 & 459.436 & 88.36 & 97.776 & 65.732 & 15.9 \\
\hline & C17-C35 & 13.830 & 874.590 & 126.585 & 159.705 & 1388.4 & 745.915 \\
\hline & $\mathrm{C} 36-\mathrm{C} 40$ & 280.26 & 39.756 & 9.8455 & 12.038 & 126.494 & 31.528 \\
\hline & Mean CF & 76.241 & 343.577 & 56.4165 & 68.6707 & 395.222 & 198.3763 \\
\hline & $\Sigma \mathrm{CF}$ & 304.96 & 1374.307 & 225.666 & 274.683 & 1580.89 & 793.5053 \\
\hline & PLI & 10.714 & 53.824 & 17.6205 & 31.3884 & 41.7426 & 15.69569 \\
\hline
\end{tabular}


Table 5: Principal component analysis of mean concentration of TPHs in rainwater

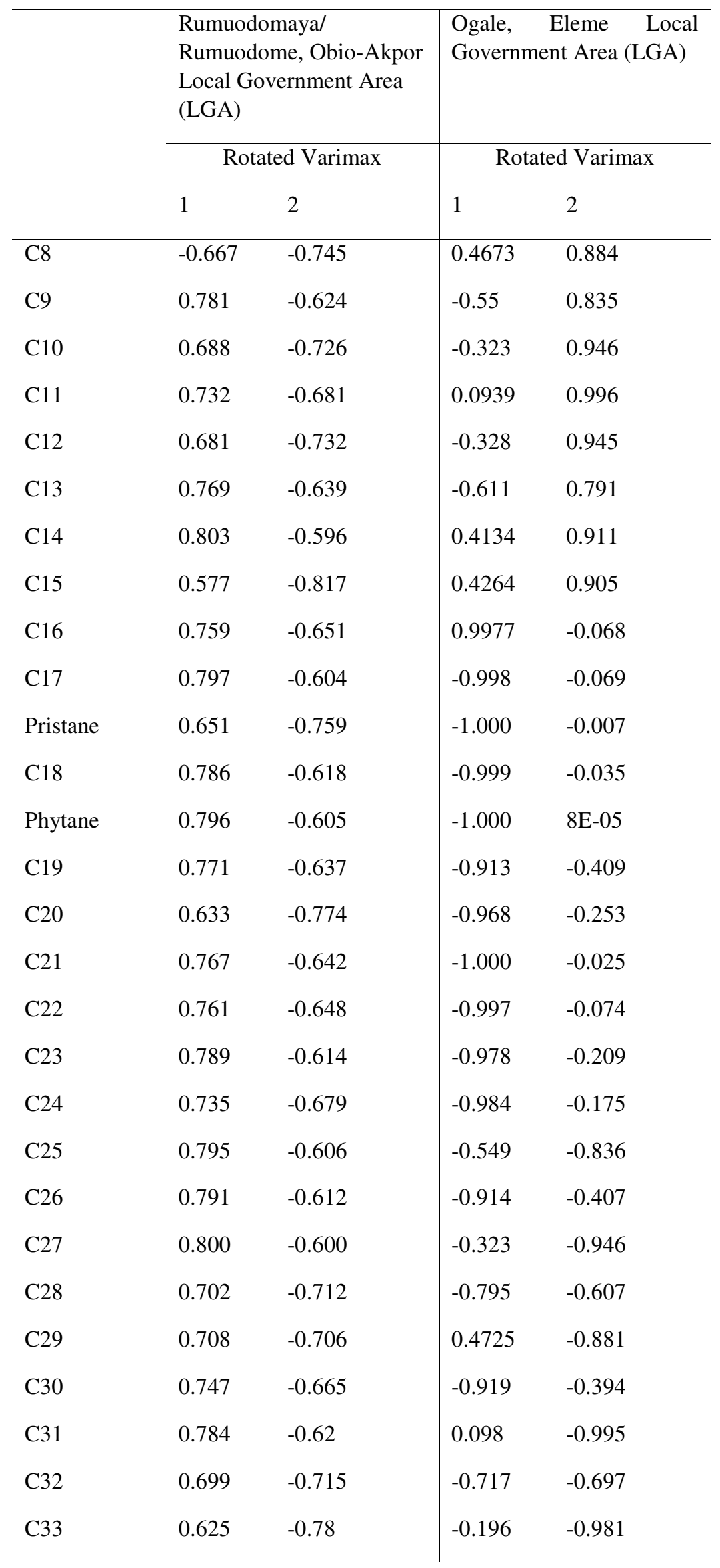




\begin{tabular}{lll|ll} 
C34 & 0.821 & -0.571 & -0.748 & -0.664 \\
C35 & 0.725 & -0.688 & -0.727 & -0.686 \\
C36 & 0.770 & -0.638 & 0.4215 & -0.907 \\
C37 & 0.103 & -0.995 & -0.987 & 0.159 \\
C38 & 0.716 & 0.698 & -0.956 & 0.293 \\
C39 & 0.093 & 0.996 & -0.997 & 0.071 \\
C40 & 0.144 & 0.99 & -1 & -0.005 \\
\hline Eigenvalue & 17.60 & 17.40 & 20.799 & 14.201 \\
Variance (\%) & 8.717 & 20.782 & 33.681 & 41.204 \\
Cumulative & 8.717 & 29.499 & 33.681 & 77.885 \\
Variance (\%) & & & & \\
\hline
\end{tabular}

Table 6: Carbon preference index (CPI) of TPHs aggregates

\begin{tabular}{llll|lll}
\hline \multicolumn{5}{c}{$\begin{array}{l}\text { Rumuodomaya/Rumuodome, Obio- } \\
\text { Akpor LGA. }\end{array}$} & \multicolumn{3}{l}{ Ogale, Eleme LGA } \\
& Early Rain & Mid Rain & Late Rain & Early Rain & Mid Rain & Late Rain \\
\hline C8-C11 & 1.034 & 0.611 & 0.362 & 0.732 & 2.768 & 1.490 \\
C12-C17 & 0.441 & 0.832 & 0.970 & 0.948 & 5.368 & 1.592 \\
C18-C25 & 1.005 & 1.287 & 0.801 & 0.724 & 0.846 & 1.193 \\
C26-C33 & 0.69 & 1.630 & 1.288 & 1.732 & 0.548 & 1.728 \\
C34-C40 & 0.084 & 0.116 & 0.174 & 0.226 & 0.118 & 0.105 \\
\hline CPI Standard & 1 & 1 & 1 & 1 & 1 & 1 \\
\hline
\end{tabular}

Table 7: Average carbon length (ACL) for TPHs aggregates 


\begin{tabular}{llll|lll}
\hline & \multicolumn{2}{l|}{$\begin{array}{l}\text { Rumuodomaya/ Rumuodome, Obio- } \\
\text { Akpor LGA }\end{array}$} & \multicolumn{2}{l}{ Ogale, Eleme LGA } \\
Odd n- alkanes & Early Rain & Mid Rain & Late Rain & Early Rain & Mid Rain & Late Rain \\
\hline C9 - C11 & 9.446 & 10.238 & 10.240 & 9.631 & 9.323 & 9.362 \\
C13 - C17 & 14.799 & 14.017 & 14.260 & 15.237 & 16.646 & 16.591 \\
C19 - C25 & 23.000 & 22.415 & 22.097 & 23.076 & 21.931 & 22.496 \\
C27 - C33 & 30.540 & 29.110 & 29.908 & 28.994 & 30.377 & 30.522 \\
C35 - C39 & 38.980 & 36.510 & 36.934 & 36.647 & 37.210 & 35.115 \\
\hline Even n-alkanes & & & & & & \\
C8 - C10 & 9.086 & 9.912 & 9.553 & 8.596 & 9.7402 & 9.240 \\
C12 - C16 & 13.620 & 14.025 & 13.581 & 13.44 & 12.711 & 15.176 \\
C18 - C24 & 20.504 & 21.232 & 21.301 & 20.523 & 20.64 & 20.919 \\
C26 - C32 & 28.087 & 28.049 & 28.689 & 28.508 & 28.600 & 28.957 \\
C34 - C40 & 39.985 & 39.340 & 39.688 & 39.365 & 39.660 & 36.727 \\
\hline
\end{tabular}

Table 8: Petroleum hydrocarbons source diagnostic ratios.

\begin{tabular}{llll|lll}
\hline & \multicolumn{3}{l|}{$\begin{array}{l}\text { Rumuodomaya/Rumuodome, Obio- } \\
\text { Akpor LGA }\end{array}$} & \multicolumn{2}{l}{ Ogale, Eleme LGA } \\
& Early Rain & Mid Rain & Late Rain & Early Rain & Mid Rain & Late Rain \\
\hline TPHs & 56.6551 & 39.5201 & 7.2283 & 9.1271 & 59.4323 & 21.9825 \\
$\mathrm{C}_{31} / \mathrm{C}_{19}$ & 0.762 & 0.979 & 0.805 & 1.47 & 0.805 & 4.314 \\
$\mathrm{~L} / \mathrm{H}$ & 0.007 & 0.690 & 0.740 & 0.787 & 0.211 & 0.120 \\
Pristane/Phytane & 1.3953 & 0.5497 & 1.9262 & 0.3753 & 1.3259 & 0.2967 \\
ACL (odd n-alkanes) & 37.705 & 21.148 & 21.246 & 20.845 & 25.234 & 28.248 \\
ACL (even n-alkanes) & 39.854 & 26.591 & 27.164 & 26.129 & 33.565 & 31.733 \\
LHC/SHC (odd n-alkanes) & 22.268 & 0.722 & 0.650 & 0.752 & 0.832 & 4.019
\end{tabular}


Table 9: Average daily intake of TPHs exposure in rainwater for adults

\begin{tabular}{|c|c|c|c|c|c|c|}
\hline Location & $\begin{array}{l}\text { TPHs } \\
\text { group }\end{array}$ & $\begin{array}{l}\text { TPHs } \\
\text { derivatives }\end{array}$ & $\begin{array}{l}\text { Exposure } \\
\text { medium }\end{array}$ & Early Rain & Mid Rain & Late Rain \\
\hline \multirow{14}{*}{$\begin{array}{l}\text { Rumuodomaya/ } \\
\text { Rumuodome, } \\
\text { Obio-Akpor } \\
\text { LGA }\end{array}$} & \multirow{8}{*}{$\begin{array}{l}\text { Aliphatic } \\
\text { PHs }\end{array}$} & \multirow[t]{2}{*}{ C6-C8 } & Ingestion & $4.20 \mathrm{E}-05$ & $6.84 \mathrm{E}-05$ & $1.14 \mathrm{E}-04$ \\
\hline & & & Dermal & 4.09E-05 & $6.66 \mathrm{E}-05$ & $1.11 \mathrm{E}-04$ \\
\hline & & \multirow[t]{2}{*}{ C9 - C18 } & Ingestion & 2.94E-04 & $1.30 \mathrm{E}-02$ & 2.38E-03 \\
\hline & & & Dermal & $2.86 \mathrm{E}-04$ & $1.27 \mathrm{E}-02$ & $2.31 \mathrm{E}-03$ \\
\hline & & \multirow[t]{2}{*}{ C19-C32 } & Ingestion & $2.11 \mathrm{E}-04$ & $1.49 \mathrm{E}-02$ & $2.12 \mathrm{E}-03$ \\
\hline & & & Dermal & $2.05 \mathrm{E}-04$ & $1.45 \mathrm{E}-02$ & $2.07 \mathrm{E}-03$ \\
\hline & & \multirow[t]{2}{*}{ C33-C40 } & Ingestion & $5.62 \mathrm{E}-02$ & $9.11 \mathrm{E}-03$ & $2.22 \mathrm{E}-03$ \\
\hline & & & Dermal & $5.47 \mathrm{E}-02$ & 8.87E-03 & $2.16 \mathrm{E}-03$ \\
\hline & \multirow{6}{*}{$\begin{array}{l}\text { Aromatic } \\
\text { PHs }\end{array}$} & \multirow[t]{2}{*}{ C6-C16 } & Ingestion & $3.06 \mathrm{E}-04$ & $1.18 \mathrm{E}-02$ & $2.33 \mathrm{E}-03$ \\
\hline & & & Dermal & $2.98 \mathrm{E}-04$ & $1.13 \mathrm{E}-02$ & $2.27 \mathrm{E}-03$ \\
\hline & & \multirow[t]{2}{*}{ C17-C32 } & Ingestion & $2.40 \mathrm{E}-04$ & 7.96E-03 & $1.97 \mathrm{E}-03$ \\
\hline & & & Dermal & 2.34E-04 & $7.75 \mathrm{E}-03$ & $1.92 \mathrm{E}-03$ \\
\hline & & \multirow[t]{2}{*}{ C33-C40 } & Ingestion & $5.62 \mathrm{E}-02$ & $9.11 \mathrm{E}-03$ & $2.22 \mathrm{E}-03$ \\
\hline & & & Dermal & $5.47 \mathrm{E}-02$ & $8.87 \mathrm{E}-03$ & $2.16 \mathrm{E}-03$ \\
\hline \multirow{14}{*}{$\begin{array}{l}\text { Ogale, } \\
\text { Eleme LGA }\end{array}$} & \multirow{8}{*}{$\begin{array}{l}\text { Aliphatic } \\
\text { PHs }\end{array}$} & \multirow[t]{2}{*}{ C6-C8 } & Ingestion & $6.72 \mathrm{E}-04$ & $3.42 \mathrm{E}-05$ & $2.11 \mathrm{E}-05$ \\
\hline & & & Dermal & $6.55 \mathrm{E}-04$ & $3.33 \mathrm{E}-05$ & $2.06 \mathrm{E}-05$ \\
\hline & & \multirow[t]{2}{*}{ C9 - C18 } & Ingestion & 3.07E-03 & $5.88 \mathrm{E}-03$ & $1.14 \mathrm{E}-03$ \\
\hline & & & Dermal & 2.99E-03 & $5.72 \mathrm{E}-03$ & $1.11 \mathrm{E}-03$ \\
\hline & & \multirow[t]{2}{*}{ C19-C32 } & Ingestion & $2.13 \mathrm{E}-03$ & $2.07 \mathrm{E}-02$ & $1.13 \mathrm{E}-02$ \\
\hline & & & Dermal & $2.07 \mathrm{E}-03$ & 2.02E-02 & $1.10 \mathrm{E}-02$ \\
\hline & & \multirow[t]{2}{*}{ C33-C40 } & Ingestion & $2.86 \mathrm{E}-03$ & $2.82 \mathrm{E}-02$ & $9.18 \mathrm{E}-03$ \\
\hline & & & Dermal & $2.78 \mathrm{E}-03$ & $2.74 \mathrm{E}-02$ & 8.93E-03 \\
\hline & \multirow{6}{*}{$\begin{array}{l}\text { Aromatic } \\
\text { PHs }\end{array}$} & \multirow[t]{2}{*}{ C6-C16 } & Ingestion & $3.12 \mathrm{E}-03$ & $1.68 \mathrm{E}-03$ & 4.19E-04 \\
\hline & & & Dermal & 3.04E-03 & $1.64 \mathrm{E}-03$ & 4.08E-04 \\
\hline & & \multirow[t]{2}{*}{ C17-C32 } & Ingestion & $2.75 \mathrm{E}-03$ & $2.50 \mathrm{E}-02$ & $1.21 \mathrm{E}-02$ \\
\hline & & & Dermal & $2.68 \mathrm{E}-03$ & $2.04 \mathrm{E}-02$ & $1.18 \mathrm{E}-02$ \\
\hline & & \multirow[t]{2}{*}{ C33-C40 } & Ingestion & $2.86 \mathrm{E}-03$ & $2.82 \mathrm{E}-02$ & $9.18 \mathrm{E}-03$ \\
\hline & & & Dermal & $2.78 \mathrm{E}-03$ & $2.74 \mathrm{E}-02$ & $8.93 \mathrm{E}-03$ \\
\hline
\end{tabular}


Table 10: Average daily intake of TPHs exposure in rainwater for children

\begin{tabular}{|c|c|c|c|c|c|c|}
\hline Location & $\begin{array}{l}\text { TPHs } \\
\text { group }\end{array}$ & $\begin{array}{l}\text { TPHs } \\
\text { derivatives }\end{array}$ & $\begin{array}{l}\text { Exposure } \\
\text { medium }\end{array}$ & Early Rain & Mid Rain & Late Rain \\
\hline \multirow{14}{*}{$\begin{array}{l}\text { Rumuodomaya/ } \\
\text { Rumuodome, } \\
\text { Obio-Akpor LGA }\end{array}$} & \multirow{8}{*}{$\begin{array}{l}\text { Aliphatic } \\
\text { PHs }\end{array}$} & \multirow[t]{2}{*}{ C6-C8 } & Ingestion & $7.65 \mathrm{E}-06$ & $1.25 \mathrm{E}-05$ & $2.08 \mathrm{E}-05$ \\
\hline & & & Dermal & $5.40 \mathrm{E}-04$ & 8.80E-04 & $1.47 \mathrm{E}-03$ \\
\hline & & \multirow[t]{2}{*}{ C9 - C18 } & Ingestion & $5.36 \mathrm{E}-05$ & 2.37E-03 & 4.33E-04 \\
\hline & & & Dermal & $3.78 \mathrm{E}-03$ & $1.67 \mathrm{E}-01$ & $3.06 \mathrm{E}-02$ \\
\hline & & \multirow[t]{2}{*}{ C19-C32 } & Ingestion & $3.84 \mathrm{E}-05$ & $2.71 \mathrm{E}-03$ & $3.87 \mathrm{E}-04$ \\
\hline & & & Dermal & $2.71 \mathrm{E}-03$ & $1.91 \mathrm{E}-01$ & 2.73E-02 \\
\hline & & \multirow[t]{2}{*}{ C33-C40 } & Ingestion & $1.02 \mathrm{E}-02$ & $1.66 \mathrm{E}-03$ & 4.05E-04 \\
\hline & & & Dermal & 7.23E-01 & $1.17 \mathrm{E}-01$ & $2.86 \mathrm{E}-02$ \\
\hline & \multirow{6}{*}{$\begin{array}{l}\text { Aromatic } \\
\text { PHs }\end{array}$} & \multirow[t]{2}{*}{ C6-C16 } & Ingestion & $5.58 \mathrm{E}-05$ & $2.11 \mathrm{E}-03$ & 4.24E-04 \\
\hline & & & Dermal & $3.94 \mathrm{E}-03$ & $1.49 \mathrm{E}-01$ & 2.99E-02 \\
\hline & & \multirow[t]{2}{*}{ C17-C32 } & Ingestion & 4.39E-05 & $1.45 \mathrm{E}-03$ & $3.60 \mathrm{E}-04$ \\
\hline & & & Dermal & $3.09 \mathrm{E}-03$ & $1.02 \mathrm{E}-01$ & $2.54 \mathrm{E}-02$ \\
\hline & & \multirow[t]{2}{*}{ C33-C40 } & Ingestion & $1.02 \mathrm{E}-02$ & $1.66 \mathrm{E}-02$ & $4.05 \mathrm{E}-04$ \\
\hline & & & Dermal & 7.23E-01 & $1.17 \mathrm{E}-01$ & $2.86 \mathrm{E}-02$ \\
\hline \multirow{11}{*}{$\begin{array}{l}\text { Ogale, } \\
\text { Eleme LGA }\end{array}$} & \multirow{8}{*}{$\begin{array}{l}\text { Aliphatic } \\
\text { PHs }\end{array}$} & \multirow[t]{2}{*}{ C6-C8 } & Ingestion & $1.23 \mathrm{E}-04$ & $6.24 \mathrm{E}-06$ & $3.85 \mathrm{E}-06$ \\
\hline & & & Dermal & $8.65 \mathrm{E}-03$ & $4.41 \mathrm{E}-04$ & 2.72E-04 \\
\hline & & \multirow[t]{2}{*}{ C9 - C18 } & Ingestion & $5.60 \mathrm{E}-04$ & $1.07 \mathrm{E}-03$ & $2.08 \mathrm{E}-04$ \\
\hline & & & Dermal & $3.95 \mathrm{E}-02$ & $7.56 \mathrm{E}-01$ & $1.47 \mathrm{E}-02$ \\
\hline & & \multirow[t]{2}{*}{ C19-C32 } & Ingestion & $3.88 \mathrm{E}-04$ & $3.78 \mathrm{E}-03$ & $2.07 \mathrm{E}-03$ \\
\hline & & & Dermal & $2.74 \mathrm{E}-02$ & $2.67 \mathrm{E}-01$ & $1.46 \mathrm{E}-01$ \\
\hline & & \multirow[t]{2}{*}{ C33-C40 } & Ingestion & $5.21 \mathrm{E}-04$ & $5.14 \mathrm{E}-03$ & $1.67 \mathrm{E}-03$ \\
\hline & & & Dermal & $3.68 \mathrm{E}-02$ & 3.63E-01 & $1.18 \mathrm{E}-01$ \\
\hline & \multirow{3}{*}{$\begin{array}{l}\text { Aromatic } \\
\text { PHs }\end{array}$} & \multirow[t]{2}{*}{ C6-C16 } & Ingestion & $5.69 \mathrm{E}-04$ & $3.06 \mathrm{E}-04$ & $7.65 \mathrm{E}-05$ \\
\hline & & & Dermal & $4.01 \mathrm{E}-02$ & $2.16 \mathrm{E}-02$ & $5.39 \mathrm{E}-03$ \\
\hline & & C17-C32 & Ingestion & $5.02 \mathrm{E}-04$ & $4.55 \mathrm{E}-03$ & $2.20 \mathrm{E}-03$ \\
\hline
\end{tabular}




$\begin{array}{lllll} & \text { Dermal } & 3.54 \mathrm{E}-02 & 3.21 \mathrm{E}-01 & 1.55 \mathrm{E}-01 \\ \text { C33-C40 } & \text { Ingestion } & 5.21 \mathrm{E}-04 & 5.14 \mathrm{E}-03 & 1.67 \mathrm{E}-03 \\ & \text { Dermal } & 3.68 \mathrm{E}-02 & 3.62 \mathrm{E}-01 & 1.18 \mathrm{E}-01\end{array}$

Table 11: Hazard Quotient for adult non-risk assessment.

\begin{tabular}{|c|c|c|c|c|c|c|}
\hline Location & $\begin{array}{l}\text { TPHs } \\
\text { group }\end{array}$ & $\begin{array}{l}\text { TPHs } \\
\text { derivatives }\end{array}$ & $\begin{array}{l}\text { Exposure } \\
\text { pathway }\end{array}$ & $\begin{array}{c}\text { Time of } \\
\text { Early Rain }\end{array}$ & $\begin{array}{l}\text { Exposure } \\
\text { Mid Rain }\end{array}$ & Late Rain \\
\hline \multirow{2}{*}{$\begin{array}{l}\text { Rumuodomaya/ } \\
\text { Rumuodome, }\end{array}$} & \multirow{8}{*}{$\begin{array}{l}\text { Aliphatic } \\
\text { PHs }\end{array}$} & C6-C8 & Ingestion & $1.05 \mathrm{E}-03$ & 171E-03 & $2.85 \mathrm{E}-03$ \\
\hline & & & Dermal & $8.17 \mathrm{E}-06$ & $1.33 \mathrm{E}-05$ & $2.22 \mathrm{E}-05$ \\
\hline \multirow[t]{6}{*}{$\begin{array}{l}\text { Obio-Akpor } \\
\text { LGA }\end{array}$} & & C9 - C18 & Ingestion & 2.94E-02 & $1.30 \mathrm{E}+00$ & $2.38 \mathrm{E}-01$ \\
\hline & & & Dermal & $2.86 \mathrm{E}-03$ & $1.27 \mathrm{E}-01$ & $2.31 \mathrm{E}-02$ \\
\hline & & C19-C32 & Ingestion & $7.02 \mathrm{E}-05$ & $4.96 \mathrm{E}-03$ & $7.08 \mathrm{E}-04$ \\
\hline & & & Dermal & $1.03 \mathrm{E}-04$ & 7.24E-03 & $1.03 \mathrm{E}-03$ \\
\hline & & C33-C40 & Ingestion & $1.87 \mathrm{E}-03$ & 3.04E-04 & $7.40 \mathrm{E}-05$ \\
\hline & & & Dermal & $2.73 \mathrm{E}-03$ & $4.43 \mathrm{E}-04$ & $1.08 \mathrm{E}-04$ \\
\hline
\end{tabular}




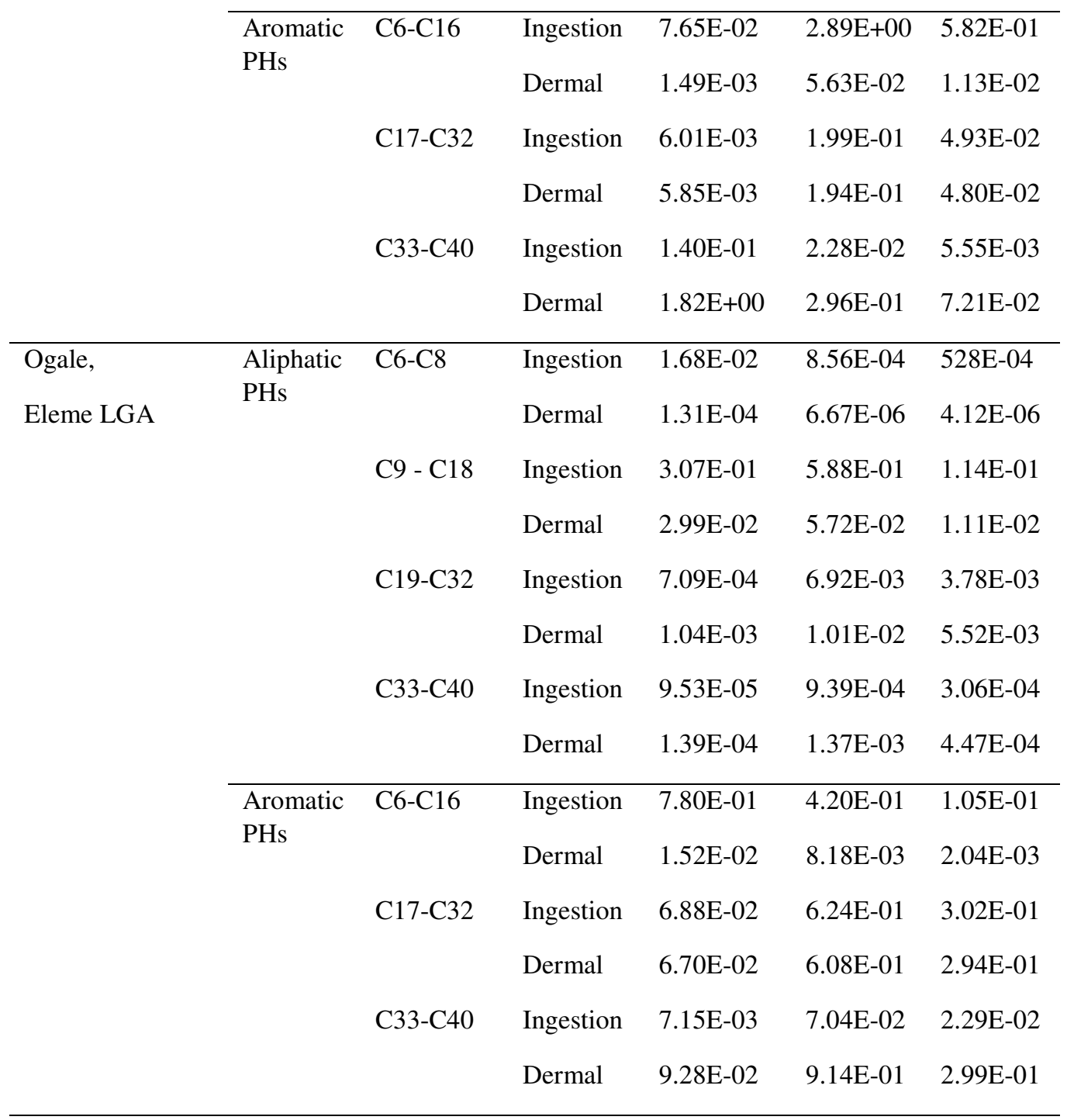


Table 12: Hazard quotient for children non-risk assessment.

\begin{tabular}{|c|c|c|c|c|c|c|}
\hline Location & $\begin{array}{l}\text { TPHs } \\
\text { group }\end{array}$ & $\begin{array}{l}\text { TPHs } \\
\text { derivatives }\end{array}$ & $\begin{array}{l}\text { Exposure } \\
\text { medium }\end{array}$ & Early Rain & Mid Rain & Late Rain \\
\hline \multirow{14}{*}{$\begin{array}{l}\text { Rumuodomaya/ } \\
\text { Rumuodome, } \\
\text { Obio-Akpor } \\
\text { LGA }\end{array}$} & \multirow{8}{*}{$\begin{array}{l}\text { Aliphatic } \\
\text { PHs }\end{array}$} & \multirow[t]{2}{*}{ C6-C8 } & Ingestion & $1.91 \mathrm{E}-04$ & $3.12 \mathrm{E}-04$ & $5.20 \mathrm{E}-04$ \\
\hline & & & Dermal & $1.08 \mathrm{E}-04$ & $1.76 \mathrm{E}-04$ & $2.93 \mathrm{E}-04$ \\
\hline & & \multirow[t]{2}{*}{ C9 - C18 } & Ingestion & $5.36 \mathrm{E}-03$ & $2.37 \mathrm{E}-01$ & 4.33E-02 \\
\hline & & & Dermal & $3.78 \mathrm{E}-02$ & $1.67 \mathrm{E}+00$ & 3.06E-01 \\
\hline & & \multirow[t]{2}{*}{ C19-C32 } & Ingestion & $1.28 \mathrm{E}-05$ & $9.05 \mathrm{E}-04$ & $1.29 \mathrm{E}-04$ \\
\hline & & & Dermal & $1.35 \mathrm{E}-03$ & $9.57 \mathrm{E}-02$ & $1.37 \mathrm{E}-02$ \\
\hline & & \multirow[t]{2}{*}{ C33-C40 } & Ingestion & $3.41 \mathrm{E}-04$ & $5.54 \mathrm{E}-05$ & $1.35 \mathrm{E}-05$ \\
\hline & & & Dermal & $3.61 \mathrm{E}-02$ & $5.86 \mathrm{E}-03$ & $1.43 \mathrm{E}-03$ \\
\hline & \multirow{6}{*}{$\begin{array}{l}\text { Aromatic } \\
\text { PHs }\end{array}$} & \multirow[t]{2}{*}{ C6-C16 } & Ingestion & $1.40 \mathrm{E}-02$ & $5.28 \mathrm{E}-01$ & $1.06 \mathrm{E}-01$ \\
\hline & & & Dermal & $1.97 \mathrm{E}-02$ & 7.44E-01 & $1.50 \mathrm{E}-01$ \\
\hline & & \multirow[t]{2}{*}{ C17-C32 } & Ingestion & $1.10 \mathrm{E}-03$ & $3.63 \mathrm{E}-02$ & 8.99E-03 \\
\hline & & & Dermal & 7.73E-02 & $2.56 \mathrm{E}+00$ & 6.34E-01 \\
\hline & & \multirow[t]{2}{*}{ C33-C40 } & Ingestion & $2.56 \mathrm{E}-02$ & $4.15 \mathrm{E}-03$ & $1.01 \mathrm{E}-03$ \\
\hline & & & Dermal & $2.41 \mathrm{E}+01$ & $3.91 \mathrm{E}+00$ & $9.52 \mathrm{E}-01$ \\
\hline \multirow{14}{*}{$\begin{array}{l}\text { Ogale, } \\
\text { Eleme LGA }\end{array}$} & \multirow{8}{*}{$\begin{array}{l}\text { Aliphatic } \\
\text { PHs }\end{array}$} & \multirow[t]{2}{*}{ C6-C8 } & Ingestion & $3.07 \mathrm{E}-03$ & $1.56 \mathrm{E}-04$ & $9.63 \mathrm{E}-05$ \\
\hline & & & Dermal & $1.73 \mathrm{E}-03$ & $8.81 \mathrm{E}-05$ & 5.44E-05 \\
\hline & & \multirow[t]{2}{*}{ C9 - C18 } & Ingestion & $5.60 \mathrm{E}-02$ & $1.07 \mathrm{E}-01$ & $2.08 \mathrm{E}-02$ \\
\hline & & & Dermal & 3.95E-01 & 7.56E-01 & $1.47 \mathrm{E}-01$ \\
\hline & & \multirow[t]{2}{*}{ C19-C32 } & Ingestion & $1.29 \mathrm{E}-04$ & $1.26 \mathrm{E}-02$ & $6.89 \mathrm{E}-04$ \\
\hline & & & Dermal & $1.37 \mathrm{E}-02$ & $1.33 \mathrm{E}-01$ & 7.29E-02 \\
\hline & & \multirow[t]{2}{*}{ C33-C40 } & Ingestion & $1.74 \mathrm{E}-05$ & $1.71 \mathrm{E}-04$ & $5.58 \mathrm{E}-05$ \\
\hline & & & Dermal & $1.84 \mathrm{E}-03$ & $1.81 \mathrm{E}-02$ & $5.90 \mathrm{E}-03$ \\
\hline & \multirow{6}{*}{$\begin{array}{l}\text { Aromatic } \\
\text { PHs }\end{array}$} & \multirow[t]{2}{*}{ С6-C16 } & Ingestion & $1.42 \mathrm{E}-01$ & $7.66 \mathrm{E}-02$ & $1.91 \mathrm{E}-02$ \\
\hline & & & Dermal & 2.01E-01 & $1.08 \mathrm{E}-01$ & $2.70 \mathrm{E}-02$ \\
\hline & & \multirow[t]{2}{*}{ C17-C32 } & Ingestion & $1.25 \mathrm{E}-02$ & $1.14 \mathrm{E}-01$ & $5.51 \mathrm{E}-02$ \\
\hline & & & Dermal & 8.49E-01 & $8.03 \mathrm{E}+00$ & $3.89 \mathrm{E}+00$ \\
\hline & & \multirow[t]{2}{*}{ C33-C40 } & Ingestion & $1.30 \mathrm{E}-03$ & $1.28 \mathrm{E}-02$ & $4.18 \mathrm{E}-03$ \\
\hline & & & Dermal & $1.23 \mathrm{E}+00$ & $1.21 \mathrm{E}+01$ & $3.93 \mathrm{E}+00$ \\
\hline
\end{tabular}


Table 13: shows values of temperature and chloride ion in ambient rain water samples within the area

\begin{tabular}{|c|c|c|c|c|c|c|}
\hline $\begin{array}{l}\text { TYPE OF } \\
\text { PARAMETER }\end{array}$ & \multicolumn{3}{|c|}{ OGALE, ELEME LGA } & \multicolumn{3}{|c|}{$\begin{array}{l}\text { RUMUDOMAYA/ RUMUODOME, OBIO- } \\
\text { AKPOR LGA. }\end{array}$} \\
\hline & Early Rain & Mid Rain & Late Rain & Early Rain & Mid Rain & Late Ran \\
\hline Temperature $\left({ }^{\circ} \mathrm{C}\right)$ & $22.57 \pm 0.26$ & $24.00 \pm 0.90$ & $25.50 \pm 0.10$ & $22.87 \pm 1.04$ & $24.25 \pm 0.35$ & $25.55 \pm 0.05$ \\
\hline $\mathrm{Cl}^{-}(\mathrm{mg} / \mathrm{L})$ & $4.77 \pm 4.55$ & $1.17 \pm 0.71$ & $0.71 \pm 0.21$ & $5.33 \pm 4.60$ & $2.01 \pm 0.11$ & $0.58 \pm 0.38$ \\
\hline
\end{tabular}
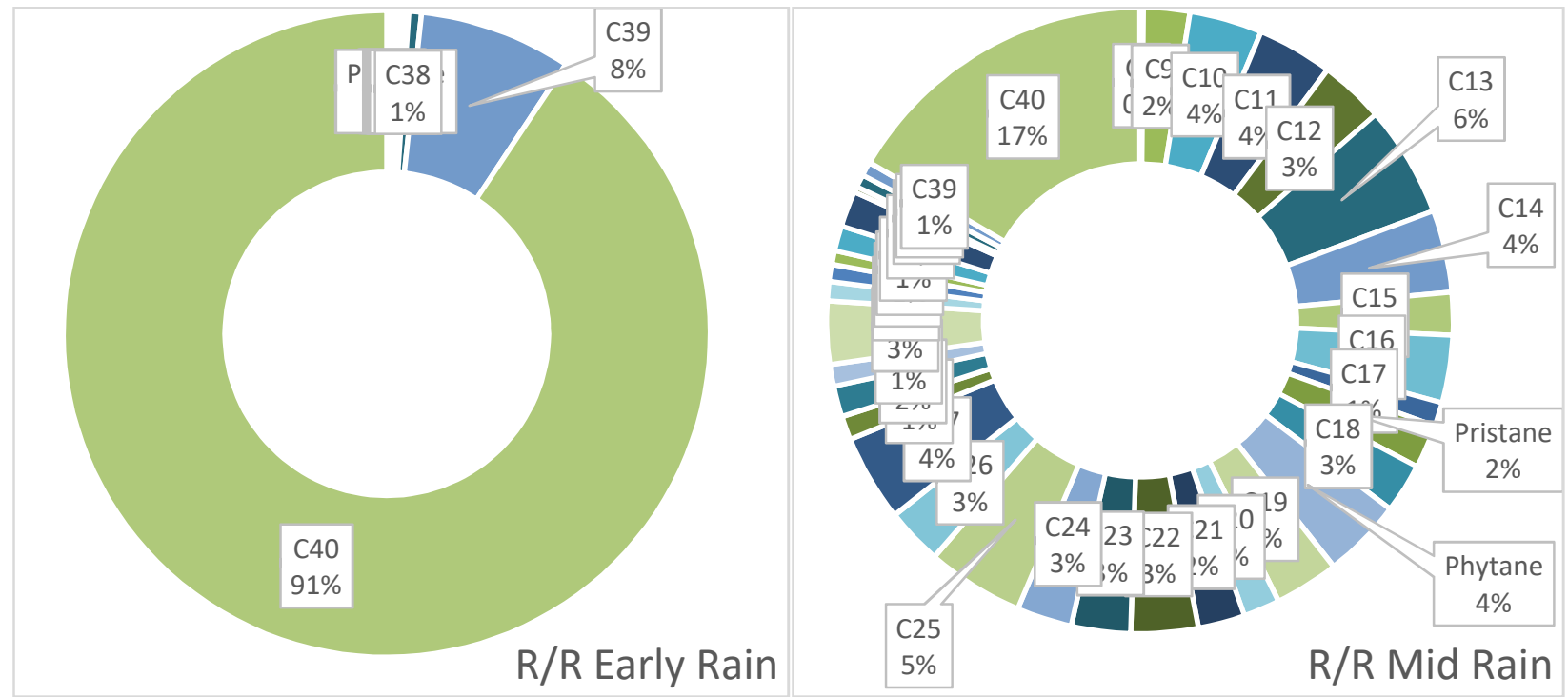


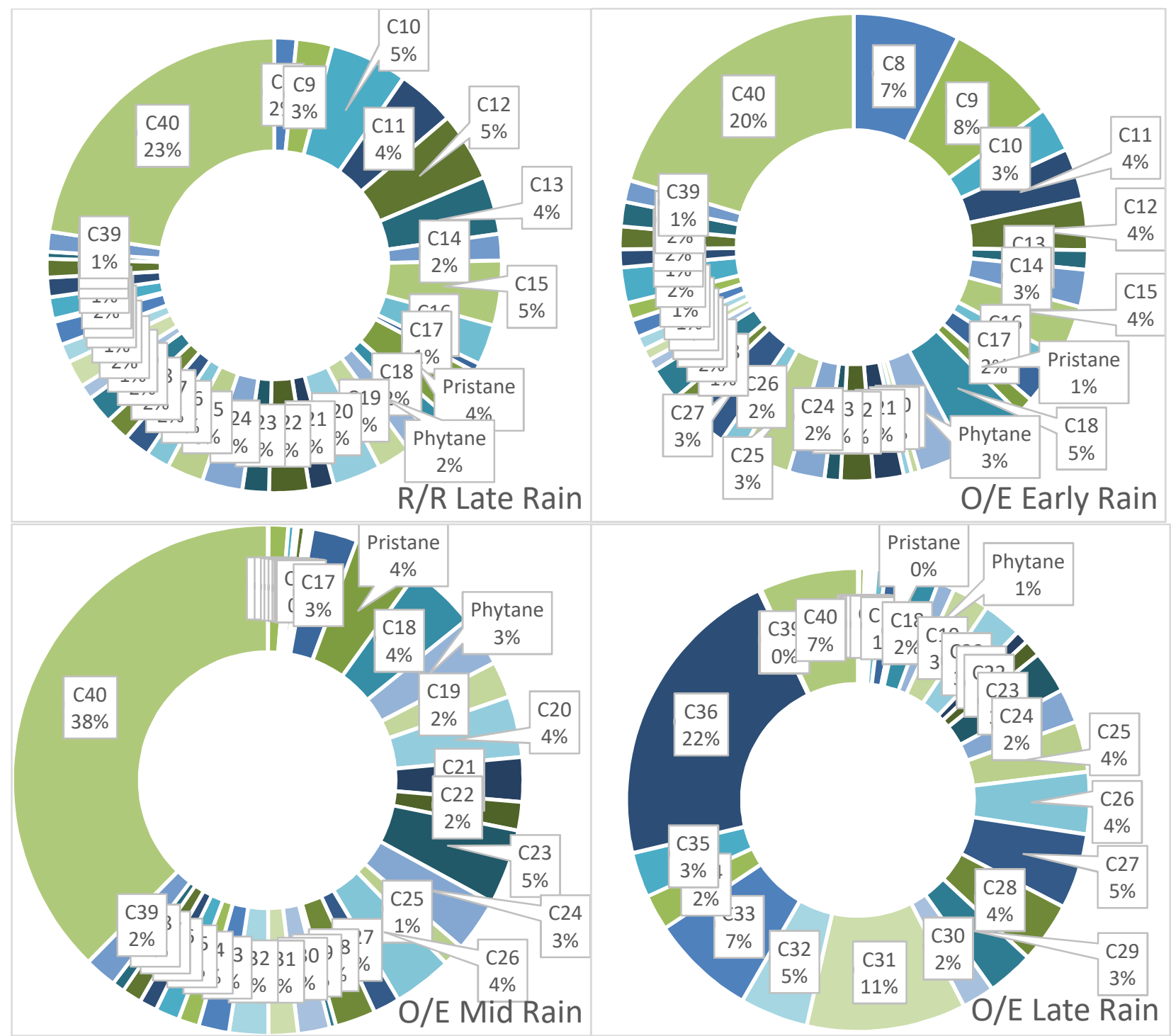

R/R: Rumuodomaya/Rumuodome, Obio-Akpor LGA; O/E: Ogale, Eleme LGA

Fig. 1: Percentage composition of TPHs across sampling period 


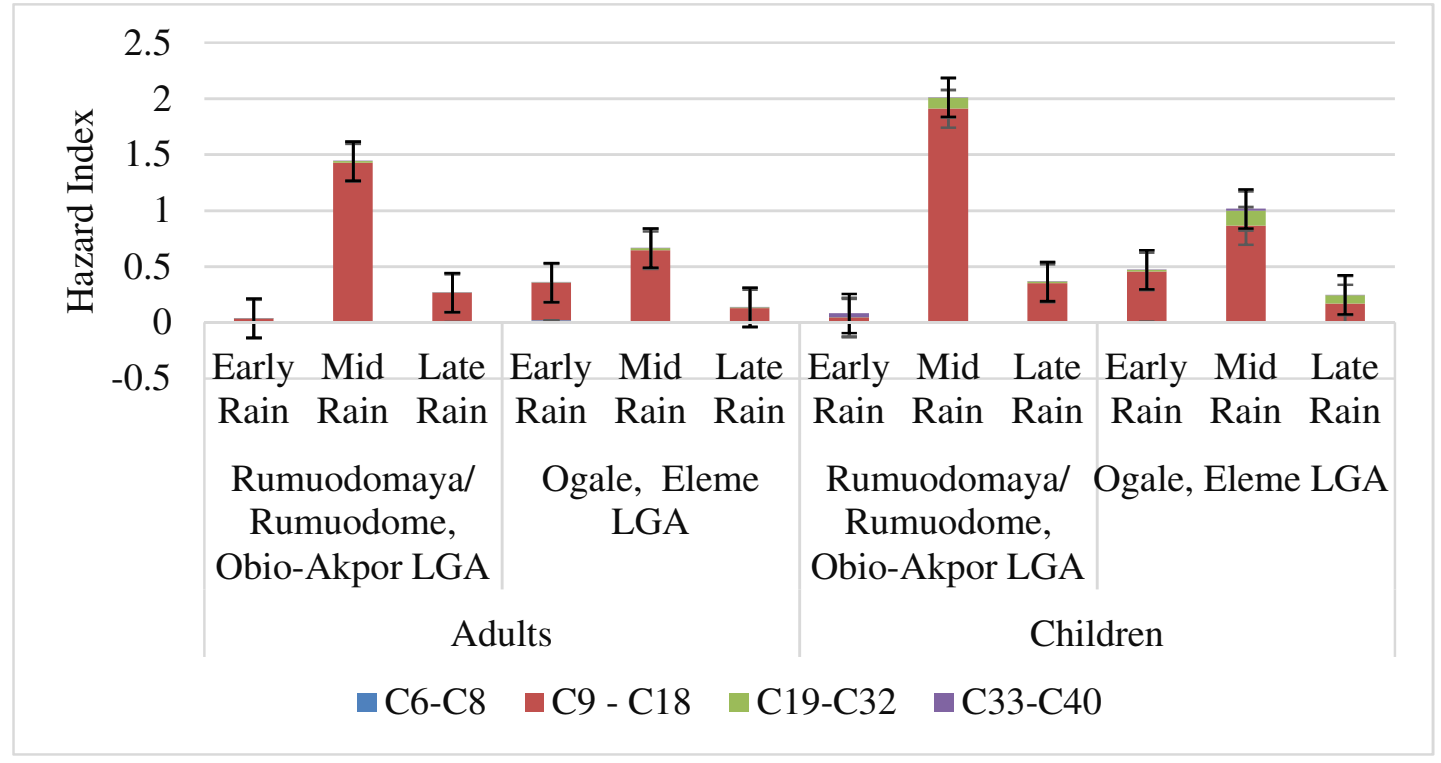

Fig 2: Hazard index of adults and children for aliphatic petroleum hydrocarbons 


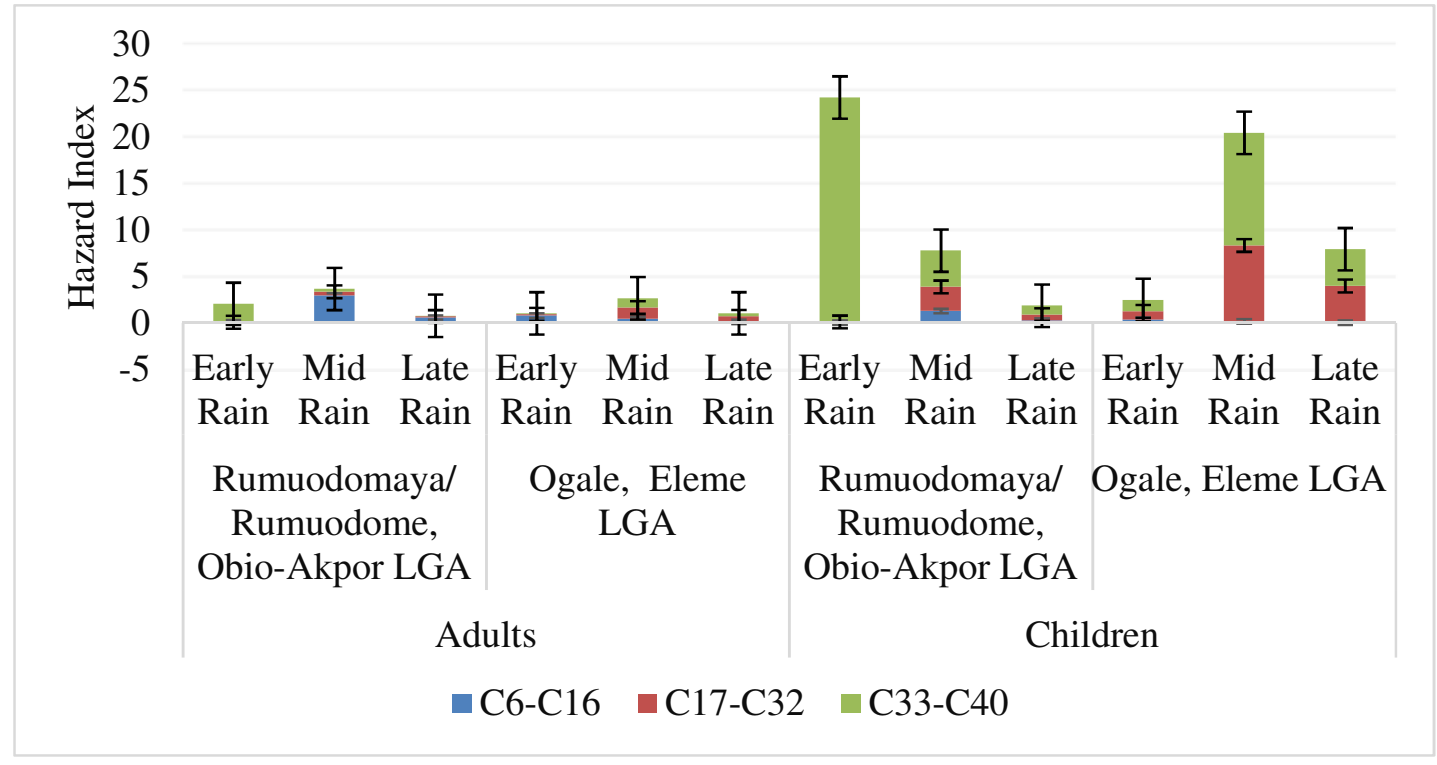

Fig 3: Hazard index of adults and children for aromatic petroleum hydrocarbons 